OPEN ACCESS

Edited by:

Roberto Sulpizio,

University of Bari Aldo Moro, Italy

Reviewed by:

Dario Pedrazzi,

Instituto de Ciencias de la Tierra

Jaume Almera (ICTJA), Spain

Federico Lucchi,

University of Bologna, Italy

${ }^{*}$ Correspondence:

Ulrich Kueppers

u.kueppers@/mu.de

Specialty section:

This article was submitted to

Volcanology,

a section of the journal

Frontiers in Earth Science

Received: 20 November 2018

Accepted: 07 May 2019

Published: 28 May 2019

Citation:

Kueppers U, Pimentel A, Ellis B, Forni F, Neukampf J, Pacheco J,

Perugini D and Queiroz G (2019)

Biased Volcanic Hazard Assessment Due to Incomplete Eruption Records on Ocean Islands: An Example

of Sete Cidades Volcano, Azores.

Front. Earth Sci. 7:122.

doi: 10.3389/feart.2019.00122

\section{Biased Volcanic Hazard Assessment Due to Incomplete Eruption Records on Ocean Islands: An Example of Sete Cidades Volcano, Azores}

\author{
Ulrich Kueppers ${ }^{1 *}$, Adriano Pimentel2,3, Ben Ellis ${ }^{4}$, Francesca Forni ${ }^{4}$, Julia Neukampf ${ }^{4}$, \\ José Pacheco ${ }^{3}$, Diego Perugini5 and Gabriela Queiroz ${ }^{3}$
}

${ }^{1}$ Department für Geo- und Umweltwissenschaften, Ludwig-Maximilians-Universität, Munich, Germany, ${ }^{2}$ Centro de Informação e Vigilância Sismovulcânica dos Açores, Ponta Delgada, Portugal, ${ }^{3}$ Instituto de Investigação em Vulcanologia e Avaliação de Riscos (IVAR), Universidade dos Açores, Ponta Delgada, Portugal, ${ }^{4}$ Institut für Geochemie und Petrologie,

ETH Zürich, Zurich, Switzerland, ${ }^{5}$ Department of Physics and Geology, University of Perugia, Perugia, Italy

It is well known that explosive volcanic eruptions pose serious hazards to local communities and may have worldwide impacts. However, the products of explosive eruptions on volcanic ocean islands are almost inevitably incompletely preserved as a significant portion of the erupted material is deposited into the ocean, thereby impeding our ability to accurately reconstruct past events, determine eruptive source parameters and ultimately assess the associated hazards. Sete Cidades is the westernmost central volcano of São Miguel Island, Azores. Although currently dormant, it has been the most active volcano on the island in the last $5 \mathrm{ky}$, with at least 17 trachytic explosive eruptions, some of which sub-Plinian, that took place inside the summit caldera. The last paroxysmal explosive eruption took place at $\sim 16 \mathrm{ka}$, enlarging the caldera to its present dimensions, and is recorded by the Santa Bárbara Formation. We here present evidence of a mid-distal deposit ( $>25 \mathrm{~km}$ from the vent) that can be correlated with the proximal (on Sete Cidades volcanic edifice) pumice fall deposit of the Santa Bárbara Formation based on deposit characteristics, textural features and geochemistry. This is the first evidence of a decimeter-thick deposit of Sete Cidades volcano in the central part of São Miguel Island, which allows to constrain eruptive source parameters and wind conditions. Given the predominant winds blowing from westerly directions, Sete Cidades is considered the most hazardous volcano for the entire island of São Miguel with its current population of $>137,000$ inhabitants. Most critically, the main harbor, only airport and hospital are located in the capital city of Ponta Delgada, $\sim 12 \mathrm{~km}$ SE from Sete Cidades caldera. In case of a future explosive eruption, under westerly blowing wind conditions, the impact on São Miguel could be catastrophic, with long-term economic consequences.

Keywords: ocean island volcano, incomplete eruption record, explosive eruption, tephra fallout, inverse problem, volcanic hazard, eruptive scenarios, São Miguel Island 


\section{INTRODUCTION}

Explosive volcanic eruptions are recognized as one of the most violent natural events that pose a plethora of hazards to local communities, economic sectors, and infrastructure, but may also cause widespread disruption of air traffic (e.g., Mazzocchi et al., 2010; Wilson et al., 2012; Biass et al., 2014; Scaini et al., 2014). This threat is even greater for volcanic islands as the ocean is a strong impediment for the evacuation of large numbers of people. The reconstruction of past eruptions on volcanic ocean islands (including the determination of eruptive source parameters) and consequently the assessment of their impact is greatly conditioned by various factors, including, but not limited to: (1) number of outcrops (small subaerial area of deposition), (2) outcrop accessibility (e.g., vegetation cover) and (3) preservation of primary features of deposits (degree of erosion and weathering). Several studies have discussed the sensitivity of determining eruptive source parameters from deposits. This is true for older deposits with incomplete preservation (e.g., Heiken and McCoy, 1984; Costantini et al., 2009; Longchamp et al., 2011) but also holds for recent and well-monitored eruptions (e.g., Spanu et al., 2016).

São Miguel is the largest and most populated $(>137,000$ inhabitants) island of the Azores archipelago and comprises three trachytic central volcanoes that have been active during the Holocene: Sete Cidades, Fogo and Furnas. The summit of all three volcanoes is truncated by a caldera. Sete Cidades (hereafter 7C), in the western end of São Miguel, is the central volcano with the highest eruptive frequency on the island in the last $5 \mathrm{ky}$ and most probably in the entire Azores archipelago (Cole et al., 2008; Queiroz et al., 2008, 2015). The caldera of 7C is located $\sim 12 \mathrm{~km}$ NW of Ponta Delgada city, the island's capital, where the main harbor, hospital, and only airport are located. Ponta Delgada is frequently downwind from $7 \mathrm{C}$ under the predominant westerly winds, posing serious concerns regarding the assessment of volcanic hazard (Pimentel et al., 2006; Cole et al., 2008; Gaspar et al., 2015).

The stratigraphy of $7 \mathrm{C}$ provides evidence for several large explosive eruptions in the past. Three paroxysmal explosive eruptions associated with different stages of evolution of the caldera have taken place between 36 and $16 \mathrm{ka}$ (Queiroz, 1997; Queiroz et al., 2015). The last paroxysmal eruption was related to the caldera-enlarging event dated at $\sim 16 \mathrm{ka} B P$ (Queiroz, 1997) and is recorded by the Santa Bárbara Formation (SBF) - the present case study. Its stratigraphy and emplacement mechanisms have been recently reanalyzed in detail by Porreca et al. (2018). In the last $5 \mathrm{ky}$, at least 17 explosive eruptions from within the summit caldera have been recognized in the stratigraphic record (Queiroz, 1997; Queiroz et al., 2008, 2015). All intra-caldera eruptions are of trachytic composition and the related deposits are dominated by ash and lapilli fall deposits. Although 7C volcano is currently dormant, with no historic eruption on land (i.e., since the 15th century), it is considered one of the most hazardous volcanoes in the Azores archipelago (Gaspar et al., 2015).

The reconstruction of the past eruptions of $7 \mathrm{C}$ volcano has been, in most cases, limited to proximal areas (i.e., on the edifice of $7 \mathrm{C}$ volcano) due to the short distance between the caldera rim and the coast $(<2-5 \mathrm{~km})$ and the overlying products from the adjacent basaltic fissure system (see Queiroz et al., 2008; Porreca et al., 2018). Based on isopach and isopleth maps, Cole et al. (2008) reconstructed eruptive source parameters of three recent $(<5 \mathrm{ky})$ intra-caldera eruptions and modeled tephra dispersal to assess the associated hazard. They showed that there is a high probability that explosive eruptions will affect the entire western third of São Miguel as well as the central part of the island. However, apart from loosely constrained isopachs of recent deposits in the area of Ponta Delgada (Queiroz, 1997; Dinis, 2006; Gonçalves, 2006), there are no reports of a distal deposit of 7C in the central part of São Miguel Island that would allow for an accurate determination of the eruption source parameters.

Here, we present evidence for a mid-distal pumice lapilli fall deposit of 7C volcano on the north coast of Fogo volcano ( $>25 \mathrm{~km}$ from 7C caldera; Figure 1). We use the term "middistal" to describe any outcrop on São Miguel beyond the edifice of $7 \mathrm{C}$ volcano as the distribution of subaerial deposits adumbrates submarine deposits at even greater distance. The goals of this paper are to: (1) demonstrate the correlation of the mid-distal fall deposit with the SBF of 7C volcano by means of textural features and geochemistry, (2) constrain eruption source parameters with/without considering the mid-distal outcrop by best-fitting tephra fallout simulations and (3) assess the potential impact of a future sub-Plinian eruption under wind conditions blowing toward Ponta Delgada city. This study has strong implications for the realistic assessment of the volcanic hazard on São Miguel Island in a worst-case scenario (large sub-Plinian eruption) and on other ocean islands vulnerable to explosive volcanic eruptions.

\section{GEOLOGICAL SETTING}

The Azores archipelago corresponds to a set of nine volcanic islands in the North Atlantic Ocean. The island of São Miguel is located on the eastern section of the NW-SE-trending Terceira Rift, that extends eastward from the Mid-Atlantic Ridge and separates the Eurasian and Nubian lithospheric plates (inset of Figure 1). São Miguel Island has an area of $744 \mathrm{~km}^{2}$ and is composed of three active trachytic central volcanoes with summit calderas, Sete Cidades (7C), Fogo (also known as Água de Pau) and Furnas (Figure 1), separated by two basaltic fissure systems, Picos and Congro. The eastern third of the island is comprised of Povoação and Nordeste volcanic systems, which are considered extinct (Gaspar et al., 2015).

The central volcano of 7C (maximum altitude of $845 \mathrm{~m}$ a.s.l.) forms the westernmost sector of São Miguel and its' caldera is located only $12 \mathrm{~km}$ NW of the city of Ponta Delgada. The volcanic edifice is strongly controlled by tectonic structures associated with the Terceira Rift (e.g., Queiroz, 1997; Carmo et al., 2015). Its summit caldera is approximately circular, $5 \mathrm{~km}$ wide and 250 $350 \mathrm{~m}$ deep, and is today partially occupied by lakes. Several intracaldera landforms prove the ongoing volcanic activity after the formation of the caldera. Their hemicircular alignment points to a ring fault with a diameter of $\sim 3.5 \mathrm{~km}$ (Kueppers et al., 2018). To the NW of the caldera, the structural control is expressed by the 


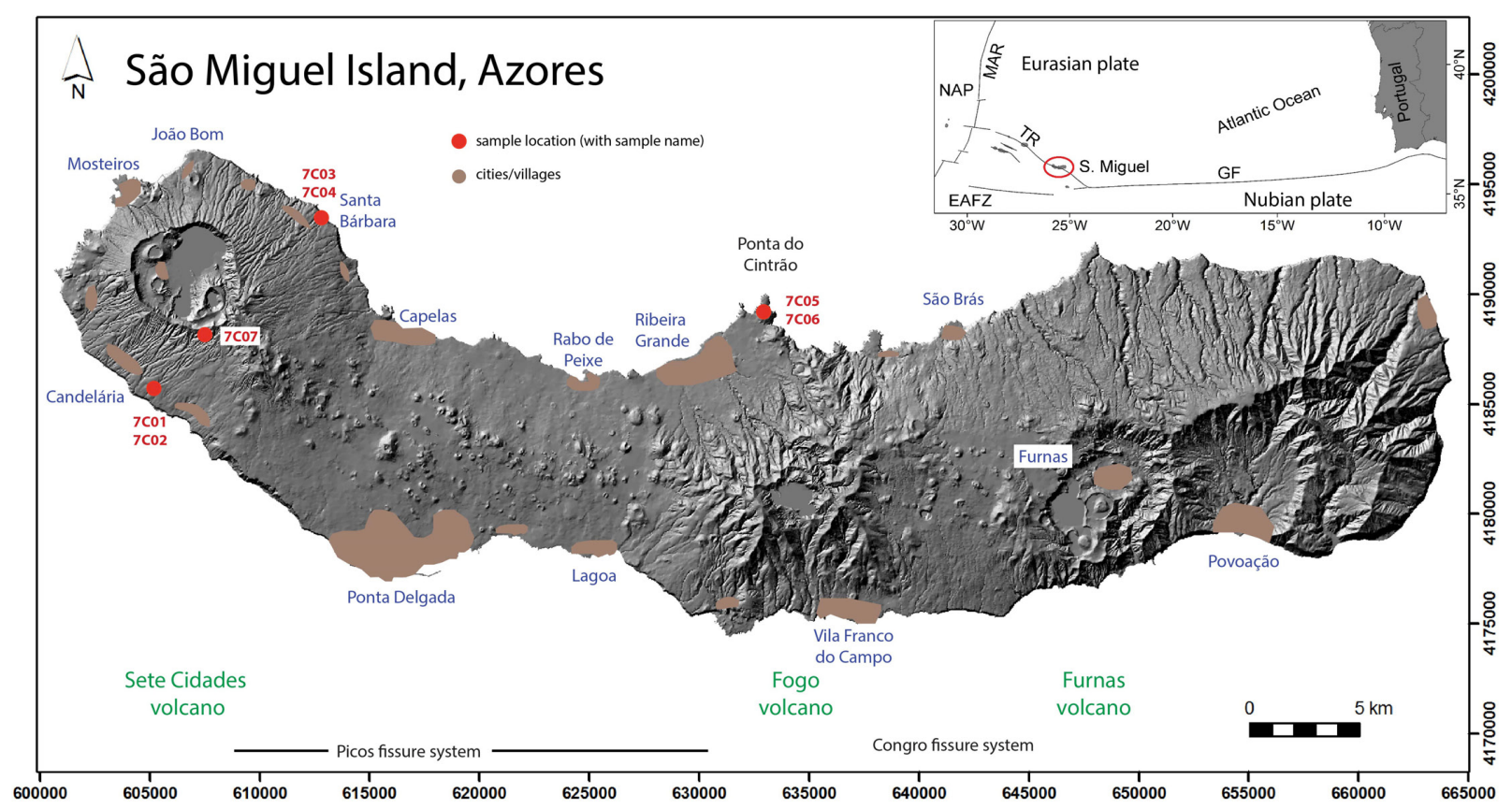

FIGURE 1 | Map of São Miguel Island showing the location of the three central volcanoes (Sete Cidades, Fogo, and Furnas), the main inhabited areas (cities and villages) and collected samples. Samples 7C01 and 7C02 collected near Candelária (outcrop A) on the southern slope of Sete Cidades volcano (7C), samples 7C03 and 7C04 near Santa Bárbara (outcrop B) on the NE slope, samples 7C05 and 7C06 at a distal location on the Ponta do Cintrão peninsula (outcrop C) and sample 7C07 collected close to 7C caldera rim (outcrop D). Inset illustrates the geographic position of São Miguel (Azores archipelago) in the Atlantic Ocean and the main structural features (NAP, North American plate; MAR, Mid-Atlantic Ridge; TR, Terceira Rift; EAFZ, East Azores Fracture Zone; GF, GLORIA Fault).

Mosteiros Graben ( $2.5 \mathrm{~km}$ wide). To the SE, a several kilometerlong rift system has repeatedly allowed for basaltic eruptions to form alignments of scoria cones (Pedrazzi et al., 2015).

The stratigraphy of 7C is divided into two lithostratigraphic groups (Queiroz, 1997; Queiroz et al., 2015): The Inferior Group includes the volcanic products dated from $\sim 210 \mathrm{ka}$ (Moore, 1990 ) to $\sim 36 \mathrm{ka}$ and is formed mainly by basaltic or trachytic lavas and to a lesser extent pyroclastic deposits (Queiroz, 1997; Beier et al., 2006; Queiroz et al., 2015). The Superior Group includes all products younger than $\sim 36 \mathrm{ka}$. It is composed of three major trachytic pyroclastic formations, namely Risco (36 ka), Bretanha (29 ka), and Santa Bárbara (16 ka) (Queiroz, 1997), related to three major phases of caldera formation, which are intercalated with deposits from subordinate eruptions. In the last $5 \mathrm{ky}$, at least 17 trachytic pumice and ash fall deposits (P1-P17) resulting from eruptions with vents inside the caldera and at least 12 flank basaltic lava flow and scoria deposits have been recognized (Booth et al., 1978; Queiroz, 1997; Queiroz et al., 2008, 2015).

According to the stratigraphic record, the eruptive history of 7C can be briefly summarized in three main stages (Queiroz, 1997; Beier et al., 2006; Queiroz et al., 2015): (1) the shieldbuilding stage of the subaerial volcanic edifice lasting from $>210$ $\mathrm{ka}$ to $\sim 36 \mathrm{ka}$ and dominated by effusive volcanism (Inferior Group), (2) the caldera-forming stage, characterized by three paroxysmal explosive eruptions associated with the formation of the present day caldera, between $\sim 36$ and $\sim 16 \mathrm{ka}$, and (3) the post-caldera stage, dominated by intra-caldera explosive eruptions and low-explosivity or effusive flank eruptions, from $\sim 16$ ka to today (Superior Group). In particular, during the last $5 \mathrm{ky}$, the eruptive frequency increased and was marked predominantly by intra-caldera eruptions, some of which of subPlinian dimensions (Queiroz, 1997; Cole et al., 2008; Queiroz et al., 2008). The last explosive eruption occurred $\sim 700$ years ago (Queiroz et al., 2008) and although 7C had no subaerial historic eruption (i.e., since Portuguese settlement in the first half of the 15th century), the high eruptive frequency makes it the most active and hazardous volcano of São Miguel Island (Gaspar et al., 2015).

\section{Overview of the Santa Bárbara Formation}

The Santa Bárbara Formation (SBF) results from the last major explosive eruption of $7 \mathrm{C}$ volcano and is related to the final phase of caldera-enlarging. Its deposits are mainly preserved along a narrow area between the caldera rim and the coastline $(<5 \mathrm{~km}$ distance), while a large portion of the pyroclastic products were deposited into the ocean (Kueppers et al., 2009; Porreca et al., 2018).

This complex pyroclastic sequence (dated at 15,740 \pm 200 uncalibrated ${ }^{14} \mathrm{C}$ years BP; Queiroz, 1997) is divided into three distinct members: Lower, Middle, and Upper. The Lower Member consists of a succession of ash beds alternating with fine-grained pumice lapilli beds, deposited mainly on the SW flank of the caldera, which is interpreted as ash fallout and 


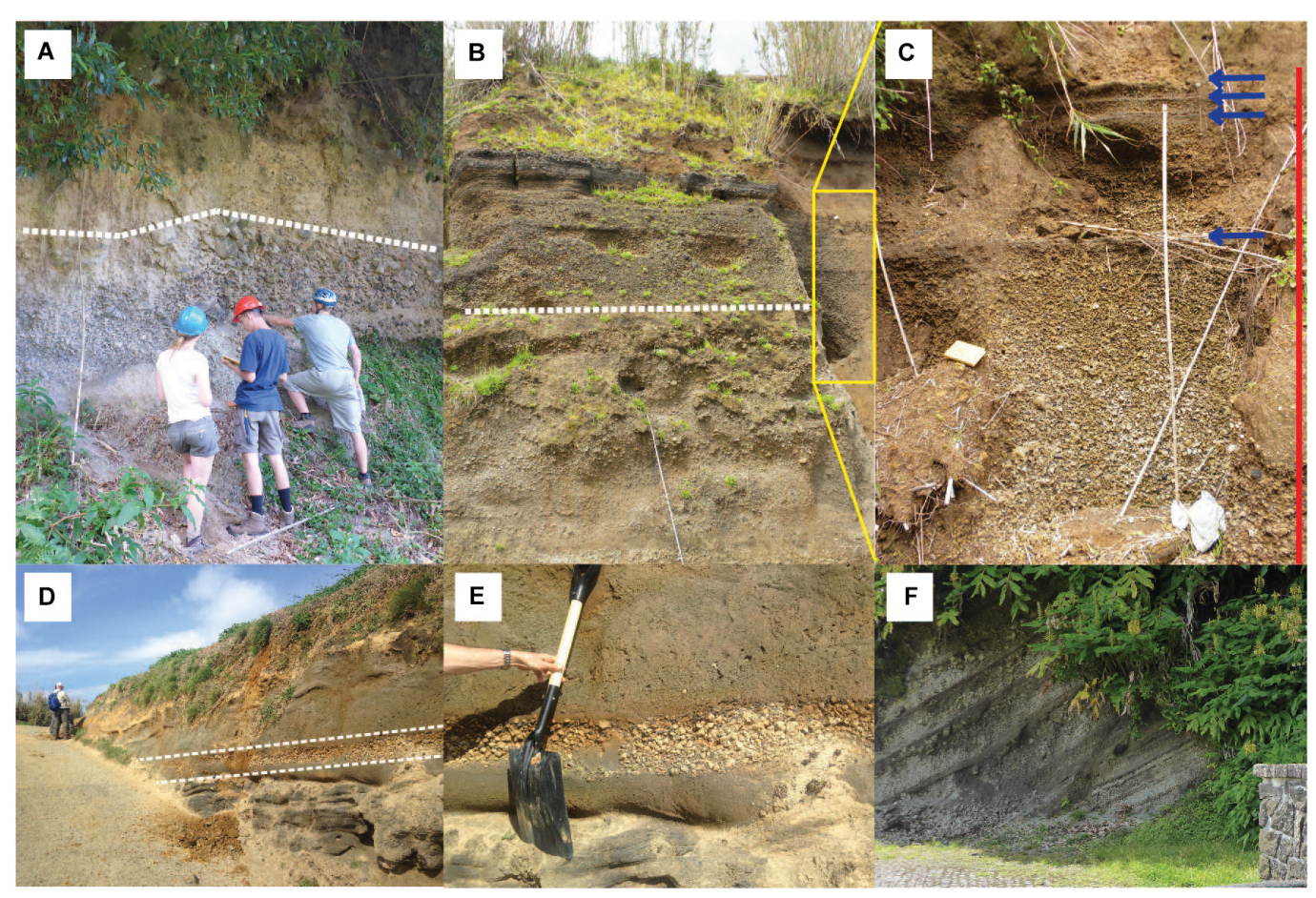

FIGURE 2 | General aspects of outcrops of the Santa Bárbara Formation (SBF). (A) Outcrop A, sampling location for samples 7C01 and 7C02 near Candelária (Figure 1). Two different PDC deposit lithofacies from the Middle Member showing massive lapilli tuffs with variable content of lithic clasts (white dashed line indicating the boundary). (B) Type locality (UK080, MP020) of the Middle and Upper Members near the village of Santa Bárbara; outcrop B for samples 7C03 and $7 \mathrm{C0} 4$ (Figure 1), showing massive lapilli tuffs in the lower half (below dashed line), overlain by massive pumice fall deposits showing normal grading (height of outcrop $8 \mathrm{~m}$ ). (C) Zoom into Figure 2B, see yellow box for stratigraphic location. General aspect of the two pumice lapilli beds of the Upper Member separated by a $12 \mathrm{~cm}$ ash layer (field book for scale). Red vertical line (approximately $3.5 \mathrm{~m}$ ) shows the vertical extent. Blue arrows indicate the presence of thin ash layers. (D) In a road cut at Ponta do Cintrão (Outcrop C for samples 7C05 and 7C06), a pumice lapilli fall deposit in between two paleosol layers shows similar features to the proximal Upper Member of the SBF (between dashed lines). (E) Close-up of the pumice lapilli fall deposit of Figure 2D, sharing many characteristics and textures of the SBF proximal deposits. (F) General aspect of layered units from a recent ( $<5 \mathrm{ky}$ ) pumice fall deposit near the Vista do Rei viewpoint; outcrop D for sample 7 C07 (spring catchment for scale). For details of (A-C) see Porreca et al. (2018).

dilute pyroclastic density current (PDC) deposits from shortlived unstable columns. The Middle Member corresponds to pumice and lithic-rich ash-lapilli tuffs, found on the SW and NE sectors, interpreted as deposited from high particle concentration PDCs (Figure 2A). The Upper Member is a pumice lapilli deposit with a narrow distribution along the NE flank, which records fallout from a sub-Plinian eruption column (Figures 2B,C, 3A). Several intercalated ash-rich horizons indicate that the eruption column at times experienced unsteadiness. The detailed stratigraphy and eruption history of the SBF are described in Queiroz et al. (2015) and more recently in Porreca et al. (2018).

A distinctive feature of the SBF is the occurrence of black trachybasaltic inclusions, also known as magmatic mafic enclaves (MME; Kueppers et al., 2009), within white or banded trachytic pumice clasts (Figures 3C,D). These are found in the Middle and Upper Members and increase upward (in both frequency and size) throughout the pyroclastic sequence (Porreca et al., 2018). The MME have been interpreted to result from magma mingling following intrusion of trachybasaltic magma into a trachytic magma reservoir (Queiroz, 1997; Kueppers et al., 2009; Porreca et al., 2018). Upon contact, the trachybasalt was quenched and experienced brittle fragmentation. The resulting fragments (MME) served as favorable sites for bubble nucleation and growth. The combined effect of thermodynamic instability and volatile exsolution, leading to increase in the magmatic pressure of the reservoir, acted as the eruption trigger and subsequent enhancement of the explosivity (see Paredes-Mariño et al., 2017; Porreca et al., 2018; Laeger et al., 2019).

\section{METHODOLOGY}

\section{Fieldwork}

The proximal deposits of the SBF outcropping on the flanks of 7C edifice were first investigated by Queiroz (1997). Kueppers et al. (2007, 2009) and ultimately Porreca et al. (2018) reinvestigated the SBF combining field methods (geological mapping and stratigraphic analysis) with laboratory analyses (granulometry, componentry, and scanning electron microscope imaging) to reconstruct the eruption history in more detail. To that end, deposit characteristics (e.g., grain size and particle shape) were investigated to decipher 


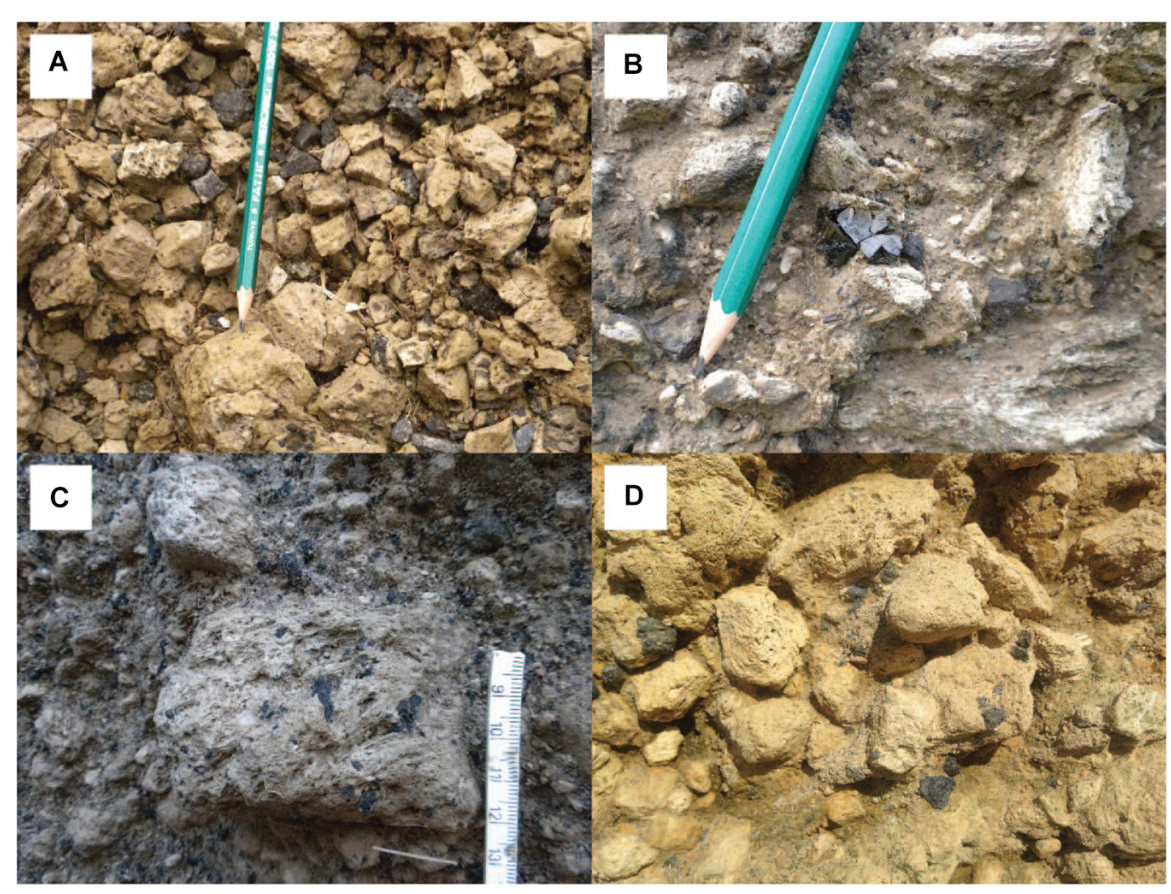

FIGURE 3 | (A) General aspect of the well-sorted fall deposit with angular pumice lapilli and subordinate lithic clasts (near Santa Bárbara village). (B) Obsidian fragments contained in the deposits of the Upper Member of the Santa Bárbara Formation (near Santa Bárbara village). (C) Large pumice lapilli with several MME (magmatic mafic enclaves) near Santa Bárbara village and (D) on the Ponta do Cintrão peninsula.

different lithofacies and ultimately constrain transport and deposition conditions. All outcrops on the 7C edifice are considered proximal. Given the prevailing winds from westerly directions (see Pimentel et al., 2006; Cole et al., 2008; Gaspar et al., 2015), a detailed field survey was extended along the north and south coasts of São Miguel Island to verify the presence of mid-distal deposits of 7C belonging to the SBF (Figure 1). This fieldwork was concentrated along coastal cliffs as outcrops inland are rare due to: (1) substantial urbanization, (2) widespread distribution of younger ( $<16 \mathrm{ky})$ basaltic tephra and lava flows from the Picos Fissure System, (3) widespread distribution of younger ( $<5 \mathrm{ky})$ trachytic fall deposits related to $7 \mathrm{C}$ and Fogo volcanoes and (4) luxuriant vegetation cover.

Seven separate samples of pumice clasts were collected at four locations (Figure 1): (1) outcrop A of PDC deposits from the SBF (Middle Member) on the south flank of 7C near the village of Candelária (samples 7C01 and 7C02; Figure 2A), (2) outcrop B of pumice fall deposit from the SBF (Upper Member) on the NE flank of 7C near Santa Bárbara village (7C03 and 7C04; Figures 2B,C), (3) outcrop C of a pumice fall bed at Ponta do Cintrão peninsula, containing pumice clasts that are texturally very similar to the ones of SBF (7C05 and 7C06; Figures 2D,E) and (4) outcrop D of a younger pumice fall deposit (P17) on the south flank of 7C caldera close to the viewpoint Vista do Rei (7C07; FigurE 2F). The sample from outcrop D was included in this study to check for geochemical variability of $7 \mathrm{C}$ products. All collected pumice clasts were in the size range of coarse lapilli. Pumice clasts from outcrops A, B, and C visually contain millimeter-sized MME (Table 1).

\section{Textural and Geochemical Analyses}

Several dozen pumice lapilli clasts were investigated macroscopically for their bubble and MME textures. Two instruments hosted at the Department for Earth and Environmental Sciences, Ludwig-Maximilians-Universität (LMU) Munich, Germany were used to investigate polished surfaces of selected pumice clasts from outcrops B and C (Cameca SX100 electron probe microanalyzer) as well as selected ash grains (scanning electron microscope HITACHI SU5000) operating at secondary electron mode with an acceleration voltage of $15 \mathrm{kV}$.

Major element compositions of glasses from pumice clasts were determined using a JEOL JXA 8200 Superprobe at the Institut für Geochemie und Petrologie, ETH Zürich, Switzerland. Operating conditions were as follows: $15 \mathrm{kV}$ accelerating voltage, current of $10 \mathrm{nA}$, counting times of $20 \mathrm{~s}$ on peak and $10 \mathrm{~s}$ on background and a defocused beam of $20 \mu \mathrm{m}$ to minimize alkali migration. The analyses were organized such that the most potentially mobile elements $(\mathrm{Na}, \mathrm{K})$ were measured first.

Trace element compositions of groundmass glass were measured by LA-ICPMS at ETH Zürich using a $193 \mathrm{~nm}$ ArF Excimer laser from Resonetics coupled to a Thermo Element XR ICPMS. Analyses involved a spot size of $29 \mu \mathrm{m}$ with an output energy of the laser beam maintained at $\sim 3.5 \mathrm{~J} / \mathrm{cm}^{2}$. Raw counts per second were reduced using identical methods to Szymanowski et al. (2015) with the MATLAB-based SILLS software (Guillong et al., 2008). NIST-610 glass was used as 
TABLE 1 | Overview of the samples used in this study.

\begin{tabular}{|c|c|c|c|}
\hline Outcrop & Location & Samples & Main macroscopic features \\
\hline$A$ & Candelária village & 7C01, 7C02 & $\begin{array}{l}\text { Rounded, whitish/yellowish pumice lapilli with magmatic mafic enclaves (MME), } \\
\text { collected from PDC deposits (Middle Member of SBF) }\end{array}$ \\
\hline B & Santa Bárbara village & 7C03, 7C04 & $\begin{array}{l}\text { Angular, whitish/yellowish pumice lapilli with MME, collected from fall deposit } \\
\text { (Upper Member of SBF) }\end{array}$ \\
\hline C & Ponta do Cintrão peninsula & $7 \mathrm{C} 05,7 \mathrm{C06}$ & Angular, whitish/yellowish pumice lapilli with MME, collected from fall deposit \\
\hline D & Near Vista do Rei viewpoint & $7 \mathrm{CO} 7$ & Angular, whitish pumice lapilli, no MME, collected from fall deposit (P17) \\
\hline
\end{tabular}

primary standard and GSD-1G as a secondary standard to monitor instrumental performance. Data were reduced using the appropriate $\mathrm{SiO}_{2}$ content (from microprobe measurements) as internal standard. Long-term ( $>5$ years) reproducibility of a range of homogeneous glass standards indicates precision typically better than $5 \%$ for elements with elemental abundances significantly (i.e., $>2 \mathrm{x}$ ) above detection limit. The full data are provided as online Supplementary Materials.

\section{Tephra Fallout Simulations}

In order to constrain the eruptive source parameters and wind conditions we used the tephra fallout model of the GISbased VORIS 2.0.1 tool (Felpeto et al., 2007) to reconstruct the dispersal and thickness of the pumice fall deposit of the Upper Member of the SBF. Tephra fallout simulations were performed with an advection-diffusion model that assumes that above the vent the mass is distributed along a vertical line following the approximation proposed in equation 3 by Armienti et al. (1988) to the model of Suzuki (1983). Away from the vent the model assumes that the transport of particles is controlled by: (1) advective effect of the wind, (2) diffusion due to atmospheric turbulence and (3) terminal settling velocity of the particles (see Folch and Felpeto, 2005; Felpeto et al., 2007).

Input parameters were obtained from published data and when unavailable through the solution of the inverse problem, i.e., by best-fitting simulation results with field data to reconstruct the pumice fall deposit (cf. Macedonio et al., 2008; Scollo et al., 2008; Bonasia et al., 2010, 2011; Moiseenko and Malik, 2019). Three tephra fallout scenarios were simulated to obtain the eruptive source parameters, wind conditions and produce volcanic hazard maps. All three scenarios assume a single-spot vent location in the center of today's $7 \mathrm{C}$ caldera, as the widespread cover by deposits related to post-caldera volcanism ( $<16 \mathrm{ky})$ does not allow to constrain the exact location of the vent(s) of the Santa Bárbara eruption.

Scenario 1 reconstructs the proximal pumice fall deposit of the Upper Member of the SBF on the NE flank of 7C volcano. To reproduce its narrow distribution a unidirectional wind profile (blowing from WSW) was assumed following the deposit dispersal. Wind intensity was obtained by best-fit with field data. Eruptive source parameters were tested in predefined intervals (erupted volume $0.1-0.4 \mathrm{~km}^{3}$; column height $10,000-20,000 \mathrm{~m}$ ) until the combination of values agreed with field data. Scenario 2 reconstructs the proximal and mid-distal distribution and thickness of the pumice fall deposit, including the pumice lapilli bed at Ponta do Cintrão peninsula. To reproduce the field observations a complex wind profile was used, with directions varying from SW-blowing wind at lower altitude to WNW-blowing wind at higher altitude. Wind intensity was obtained through best-fit. Eruptive source parameters were changed within the same pre-defined intervals as in scenario 1 until their combination fitted proximal and distal field data. Finally, scenario 3 simulates the potential impact of an explosive eruption with the same eruptive source parameters of scenario 2 under wind conditions blowing from NW, i.e., toward the city of Ponta Delgada. This aims to reproduce the worst-case scenario of a future sub-Plinian eruption of $7 \mathrm{C}$ volcano (Cole et al., 2008; Queiroz et al., 2008), with the highest impact on the island's key infrastructure and economy, giving the predominant westerly blowing winds (see details of wind statistical analyses in Pimentel et al., 2006; Cole et al., 2008; Gaspar et al., 2015). Table 2 summarizes the main input parameters used in the simulation of the three scenarios.

\section{RESULTS}

\section{Field Data}

The deposits of the SBF outcrop discontinuously along the flanks of 7C volcano, except on the SE sector where they are probably covered by basaltic products from the Picos Fissure System (see Porreca et al., 2018). It is likely that the SBF products were deposited over the entire volcanic edifice. However, due to significant erosion, vegetation cover and younger overlying deposits, the general stratigraphy and sedimentary features have been deciphered by the analysis of isolated outcrops. Stratigraphic correlations were facilitated by the presence of MME in juvenile pumice clasts, which increase in frequency and size toward the top of the pyroclastic sequence (Queiroz et al., 2015; Porreca et al., 2018).

The SBF Upper Member is only found in an area of approximately $10 \mathrm{~km}^{2}$ on the NE flank of 7C. It is a typical fall deposit (Figures 2B,C, 3A) with clast-supported fabric of well-sorted ( $\sigma \phi 1.2)$, coarse-grained $(\mathrm{Md} \phi-3.5)$ angular pumice lapilli clasts that are generally light-colored, occasionally banded, and contain MME up to $15 \%$ of the volume. Larger pumice clasts occur occasionally (average maximum size of the three largest clasts up to $15 \mathrm{~cm}$ ). Centimeter-sized angular lithic clasts (up to $10 \%$ of total volume; basaltic and trachytic lava fragments and hydrothermally altered clasts) and minor obsidian chips are also present (Figure 3B). 
In some outcrops, this deposit can be subdivided into two pumice fall beds separated by an ash-rich layer $(12 \mathrm{~cm}$ thick, Figures $2 \mathrm{~B}, \mathrm{C}$ ). The basal bed is thicker (up to $1.4 \mathrm{~m}$ ), coarsegrained $(\mathrm{Md} \phi-3.5)$ and more widespread than the top bed. The basal pumice lapilli bed does not show significant grain size variation, which suggests stable eruptive conditions (for more details see Porreca et al., 2018). The thin ash-rich layer found between the two pumice beds is weakly stratified and is interpreted as recording unsteadiness of the eruption column, possibly related to a small partial column collapse and generation of dilute PDCs. The top pumice lapilli bed is generally less than $1 \mathrm{~m}$ thick, overall finer-grained $(\operatorname{Md} \phi-1.3)$ and shows slight fining upward. In the upper part of the top bed we occasionally find several thin layers of coarse-ash to fine-grained lapilli clasts. While the fining-upward trend indicates waning of the eruption column, these thin layers indicate a repetitive pattern of localized partial erosion and/or reworking of by dilute PDCs or strong winds during the final stages of deposition of the Upper Member. The narrow area of distribution of the Upper Member of the SBF, the small number of outcrops and the rather homogeneous thickness and grain size do not allow for the reconstruction of reliable isopachs and isopleths.

In 2008, we found one additional depositional area at Ponta do Cintrão peninsula (altitude of $103 \mathrm{~m}$ a.s.l.), on the north coast of São Miguel Island (i.e., on the north flank of Fogo volcano) $>25 \mathrm{~km}$ east of 7C caldera (Kueppers et al., 2009, Figure 1). Here a pumice lapilli bed (up to $30 \mathrm{~cm}$ thick, Figures 2D,E) shows visually identical features to those reported for the proximal pumice fall deposit of the Upper Member of the SBF. It is a clast-supported, well-sorted pumice fall bed, with yellowish, angular, lapilli-sized pumice clasts (average maximum clast size of the three largest clasts is $4 \mathrm{~cm}$ ) distinctive for the striking presence of small black inclusions. Lithic clasts (primarily basaltic lava fragments) are subordinate and up to $2 \mathrm{~cm}$ size. All characteristics of this pumice lapilli bed point to a primary deposit. The upper and lower limits are well defined by paleosols (Figure 3D). The underlying paleosol is fine-grained, $10-15 \mathrm{~cm}$ thick and of beige color. The overlying paleosol is considerably thicker $(>70 \mathrm{~cm})$ and contains (sub-)rounded pumice lapilli.

Later, Ponte (2013) described several outcrops of a locally restricted pumice lapilli bed along the north flank of Fogo volcano with similar features to the pumice bed described in this study. The area covered extends for about $9 \mathrm{~km}$ between the Ponta do Cintrão peninsula and São Brás village, at altitudes between 54 and $233 \mathrm{~m}$ a.s.l. (see Supplementary Figure S1). It is described as a fall deposit (up to $15-25 \mathrm{~cm}$ thick) with yellowish lapillisized pumice clasts (maximum size of $4 \mathrm{~cm}$ with abundant black scoriaceous inclusions), dispersed lithics (1-2 cm across) and small obsidian fragments. Ponte (2013) stated that it was not possible to correlate this bed to the stratigraphy of Fogo volcano. The textural description matches our findings.

\section{Textural Aspects}

Pumice lapilli clasts from the proximal SBF outcrops (A and $\mathrm{B}$; PDC and fall deposits, respectively) and the mid-distal bed at Ponta do Cintrão peninsula (outcrop C) share the same textural features (Kueppers et al., 2009; Fahrner, 2012; Ortenzi, 2014). The pumice clasts are light-colored (whitish or yellowish),

TABLE 2 | Input parameters used for the simulation of scenarios 1, 2, and 3 with VORIS 2.0.1.

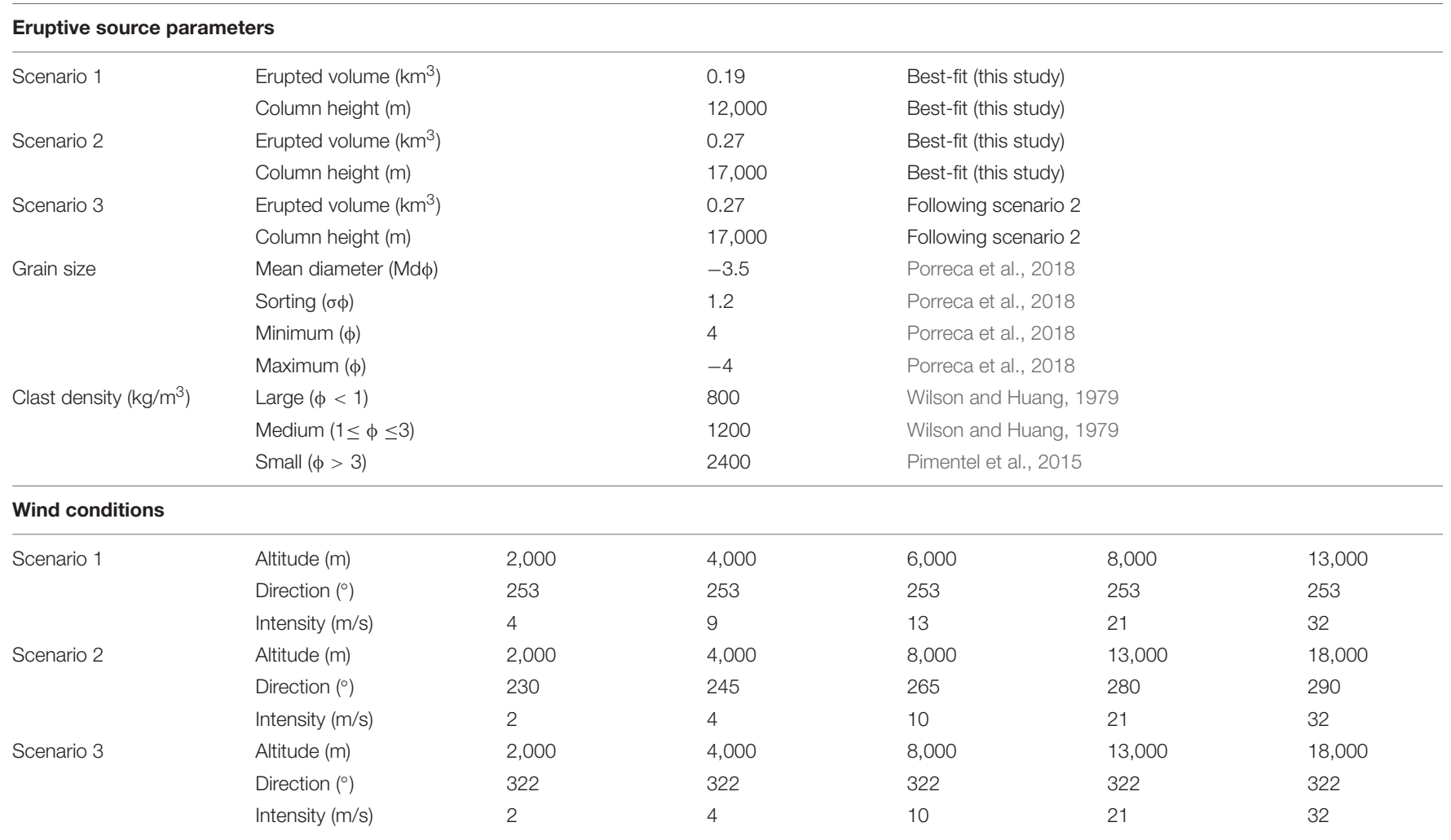




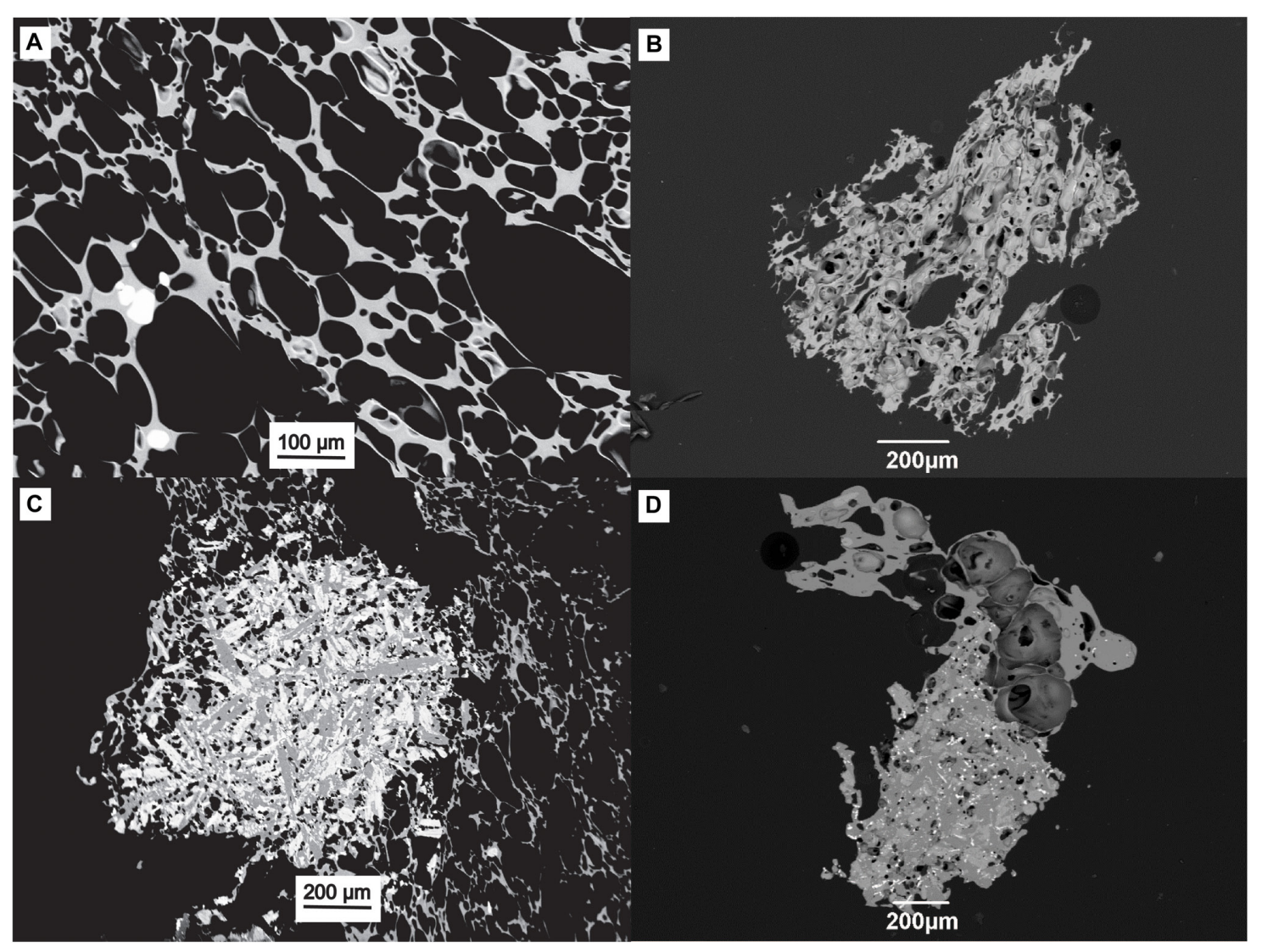

FIGURE 4 | Representative samples [lapilli (A,C) and ash (B,D)] from outcrops B and C, showing highly vesicular and almost aphyric trachytic pumice textures (A,B) and magmatic mafic enclaves (MME) of microcrystalline trachybasalt $(\mathbf{C}, \mathbf{D})$ in ash grains with low aspect ratio bubbles.

although banded clasts also occur. They are almost aphyric (up to $2 \mathrm{vol} \%$ phenocryst content) and highly vesicular (up to 80 vol\% vesicularity, Figure 4A), exhibiting two populations of bubbles and high bubble connectivity (Figures 4A,B). While few large bubbles (up to $10 \mathrm{~cm}$ long, bubble aspect ratio 2:1) can be found in the largest clasts, the dominant bubble population is commonly $<150 \mu \mathrm{m}$ long. Approximately $30 \%$ of the pumice clasts contain mafic magmatic enclaves (MME). They are variable in size and shape, ranging from single (sub-)millimetersized, scoriaceous fragments to MME-enriched areas up to $10 \mathrm{~cm}$ in large pumice clasts. The MME are microcrystalline and poorly vesicular, commonly showing diktytaxitic texture (Figures 4C,D) interpreted as evidence of quench crystallization (see Paredes-Mariño et al., 2017; Porreca et al., 2018; Laeger et al., 2019). In many pumice clasts the interior wall of large bubbles is dotted with angular MME. No MME are found within the small bubbles. By contrast, the pumice clasts from outcrop D of a recent pumice fall deposit (P17) are angular, whitish and almost aphyric but do not contain MME. The textural features of pumice clasts as well as of MME from outcrops $\mathrm{A}, \mathrm{B}$, and $\mathrm{C}$ are very similar, confirming that the Ponta do Cintrão pumice bed can be correlated with the Upper Member of the SBF, as already indicated by similar lithofacies. In order to further confirm this hypothesis, the geochemistry of pumice clasts from 4 different outcrops has been investigated.

\section{Geochemistry}

All normalized glass major elemental compositions from this study plot within the trachyte field of a classical total alkali vs. silica (TAS) diagram, similar to other compositions reported from 7C volcano (Beier et al., 2006; Queiroz et al., 2015; Johansson et al., 2017). Samples from SBF outcrops A and B, and Ponta do Cintrão outcrop C (7C01 to 7C06, see Figure 1 for location) overlap in all major elements, while sample 7C07 from outcrop $\mathrm{D}$ is distinguished on the basis of a higher $\mathrm{SiO}_{2}$ content and lower $\mathrm{CaO}, \mathrm{MgO}$, and $\mathrm{TiO}_{2}$ (Figure 5 and Table 3). Recently published glass major elements from pumices clasts (with and without flow bands) of the SBF (Laeger et al., 2019) overlap with our samples 7C01-7C06. The observed spread is due to the focus of Laeger et al. (2019) on the analysis of banded pumice clasts, which contain filaments of a less evolved composition, due to magma mixing/mingling. Glass geochemistry data from Fogo and Furnas volcanoes (Johansson et al., 2017) are also shown for comparison and clearly reveal different compositions (Figure 5).

In terms of trace elemental abundances, a similar behavior is observed with samples 7C01-06 showing identical compositions while sample 7C07 is compositionally distinct (Figure 5; the 

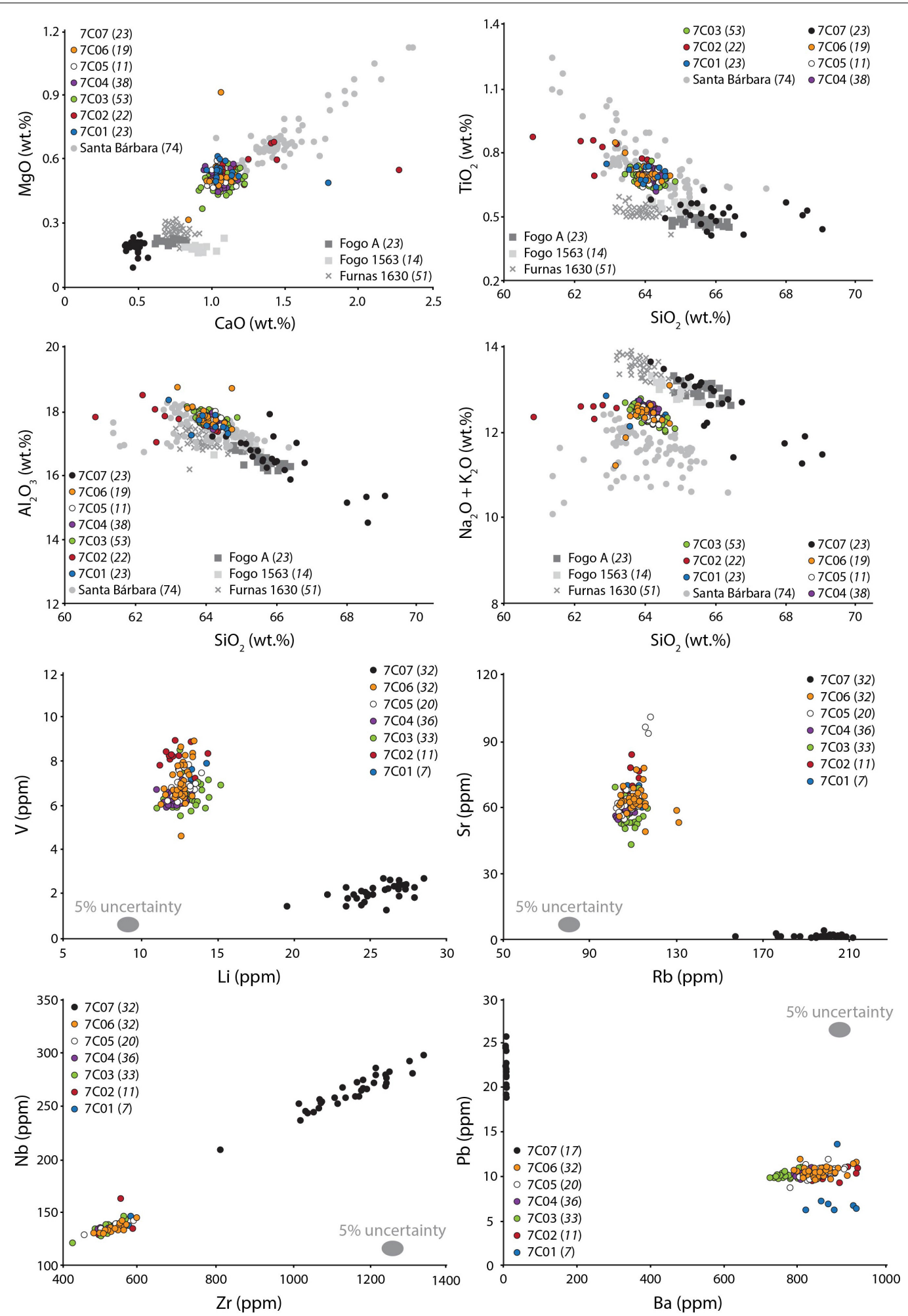

FIGURE 5 | Glass geochemistry results. Top 4 panels: major elements plotted vs. silica of glasses from Sete Cidades (7C), Fogo, and Furnas volcanoes. Samples 7C01 through 7C06 (macroscopically homogeneous pumices, colored circles) form clusters owing to the genetic relationship; sample 7C07 (black circles) is compositionally different. Gray circles (banded pumices of the SBF, Laeger et al., 2019) show larger spread owing to magma mixing/mingling. Comparative samples from Fogo (Fogo A and Fogo 1563) and Furnas (Furnas 1630) volcanoes (Johansson et al., 2017). All data are spot analysis obtained with EPMA. Lower 4 panels: Selected trace element plots supporting the genetic relationship of 7C01-04 to 7C05-06, evidencing a distal deposit of 7C on Ponta do Cintrão. All data were measured by LA-ICPMS. (Numbers in brackets indicate the number of measurements). 
complete trace element dataset is given in Supplementary Table S1). The compositional difference between samples 7C0106 and 7C07 is preserved across the range of geochemical affinities, being readily observed in compatible (e.g., Ba, Sr), incompatible (e.g., $\mathrm{Zr}, \mathrm{Hf}, \mathrm{Nb}$ ) and moderately incompatible (e.g., Li) elements. The low Ba content in sample 7C07 is notable, with values approximating the analytical limits of detection $(\sim 3 \mathrm{ppm} \mathrm{Ba})$. While somewhat unusual, these extremely low Ba contents in sample 7C07 were measured in two different analytical sessions where trace elemental abundances of all samples showed good agreement between the two sessions. A final difference comes in the total abundances of the rare earth elements (REE) which are significantly higher (418-691, avg. $583 \mathrm{ppm}$ ) in sample 7C07 than in the six other samples (273-432, avg. $333 \mathrm{ppm}$ ).

Overall, the geochemical results (Figure 5) are strongly supportive of the correlation of the outcrop at Ponta do Cintrão peninsula with the proximal Upper Member deposit of the SBF, as assumed on the basis of textural features and field lithofacies data. The glass composition of sample 7C07 from a younger $(<5 \mathrm{ka})$ pumice fall deposit shows that compositionally distinct magmas have been erupted from $7 \mathrm{C}$ volcano. This further underscores the significance of the identical geochemistry shown in samples 7C01-06.

\section{Eruptive Source Parameters and Wind Conditions}

Spatial distribution and thickness variation of the Upper Member pumice fall deposit of the SBF allowed us to constrain the eruptive source parameters and wind conditions during the final phase of this eruption. Three different fallout scenarios were simulated, always assuming a vent located in the center of the present summit caldera of 7C volcano (see Methodology section for details).

The tephra fall map of scenario 1 (Figure 6) takes into consideration the proximal outcrops of the Upper Member pumice fall deposit along the $\mathrm{NE}$ flank of $7 \mathrm{C}$, assuming a unidirectional wind profile blowing from WSW $\left(253^{\circ}\right)$ and wind intensities increasing upward from 4 to $32 \mathrm{~m} / \mathrm{s}$. The solution of the inverse problem for the proximal deposits estimated an erupted volume of $0.19 \mathrm{~km}^{3}$ and a column height of 12,000 m (Table 2). The simulation results are in good agreement with the observed distribution and thickness (up to $3 \mathrm{~m}$ ) of the Upper Member outcrops (Porreca et al., 2018).
The tephra fall map resulting from scenario 2 (Figure 7) reconstructs a larger spatial distribution of the SBF Upper Member by including the proximal deposits and the middistal pumice lapilli bed recognized at Ponta do Cintrão. To reproduce the observed deposit distribution and thickness, a more complex wind profile (obtained through best-fit) was used in the simulation. Wind directions vary from SW $\left(230^{\circ}\right)$ at lower attitude $(2,000 \mathrm{~m}$ a.s.l. $)$ to $\mathrm{WNW}\left(290^{\circ}\right)$ at higher altitude $(18,000 \mathrm{~m}$ a.s.l.), while wind intensities range from 2 to $32 \mathrm{~m} / \mathrm{s}$ (see Table 2). These wind directions are in good agreement with the prevailing westerly blowing winds (Pimentel et al., 2006; Cole et al., 2008; Gaspar et al., 2015). Eruptive source parameters obtained by solving the inverse problem yielded a tephra volume of $0.27 \mathrm{~km}^{3}$ and column height of $17,000 \mathrm{~m}$ (Table 2) for the final phase of the eruption, related to the deposition of the Upper Member. The simulation adequately reproduces the distribution and thickness of the proximal pumice fall deposit, the measured thickness at Ponta do Cintrão outcrop $(30 \mathrm{~cm})$ and the rather homogenous thickness $(25$ to $15 \mathrm{~cm}$, negatively correlated with increasing distance from 7C volcano) along the north flank of Fogo volcano described by Ponte (2013; see Supplementary Figure S1). Although not shown in the map, the simulation predicts that the entire north coast of São Miguel Island is affected by tephra fall ( $>5 \mathrm{~cm}$ thick).

Finally, the tephra fall map from scenario 3 (Figure 8) simulates the potential impact of a sub-Plinian eruption of 7C, under a unidirectional wind profile blowing from $\mathrm{NW}\left(322^{\circ}\right)$, using the same wind intensities $(2-32 \mathrm{~m} / \mathrm{s})$ and eruptive source parameters (erupted tephra volume $0.27 \mathrm{~km}^{3}$; column height $17,000 \mathrm{~m}$ ) obtained for scenario 2 (Table 2). Considering the predominant westerly wind directions, this is a highly plausible future scenario. The simulation predicts that the capital city of Ponta Delgada, located $\sim 12 \mathrm{~km}$ SE of $7 \mathrm{C}$ volcano, can be affected by $0.5-1 \mathrm{~m}$ of tephra fall.

\section{DISCUSSION}

The $\sim 16$ ka eruption of $7 \mathrm{C}$ volcano, recorded by the SBF, was the last paroxysmal explosive event that enlarged the summit caldera to its present-day dimensions (Queiroz et al., 2015; Porreca et al., 2018). Although no continuous deposit is preserved along the flanks of the volcano, the distinctive presence of MME in juvenile pumice clasts allows for unambiguous correlation of the deposits of the SBF.

TABLE 3 | Overview of normalized values of major elements for the 7 different sample sets.

\begin{tabular}{|c|c|c|c|c|c|c|c|c|c|c|}
\hline Major elements normalized & $\mathrm{SiO}_{2}$ & $\mathrm{Na}_{2} \mathrm{O}$ & $\mathrm{CaO}$ & $\mathrm{K}_{2} \mathrm{O}$ & $\mathrm{FeO}$ & $\mathrm{MgO}$ & Cl & $\mathrm{TiO}_{2}$ & $\mathrm{MnO}$ & $\mathrm{Al}_{2} \mathrm{O}_{3}$ \\
\hline $7 \mathrm{C01}$ & 64.08 & 6.91 & 1.09 & 5.53 & 3.04 & 0.54 & 0.16 & 0.69 & 0.17 & 17.66 \\
\hline 7C02 & 63.64 & 6.95 & 1.27 & 5.53 & 3.12 & 0.56 & 0.15 & 0.74 & 0.16 & 17.69 \\
\hline $7 \mathrm{CO3}$ & 64.11 & 6.76 & 1.07 & 5.62 & 3.03 & 0.50 & 0.14 & 0.68 & 0.19 & 17.81 \\
\hline $7 \mathrm{CO} 4$ & 64.17 & 6.89 & 1.04 & 5.56 & 3.07 & 0.51 & 0.13 & 0.68 & 0.18 & 17.67 \\
\hline 7C05 & 64.13 & 6.81 & 1.05 & 5.53 & 3.08 & 0.52 & 0.15 & 0.68 & 0.18 & 17.80 \\
\hline 7C06 & 64.02 & 6.76 & 1.05 & 5.60 & 3.03 & 0.54 & 0.18 & 0.68 & 0.17 & 17.89 \\
\hline 7C07 & 66.17 & 7.19 & 0.48 & 5.43 & 3.00 & 0.19 & 0.34 & 0.51 & 0.23 & 16.44 \\
\hline
\end{tabular}




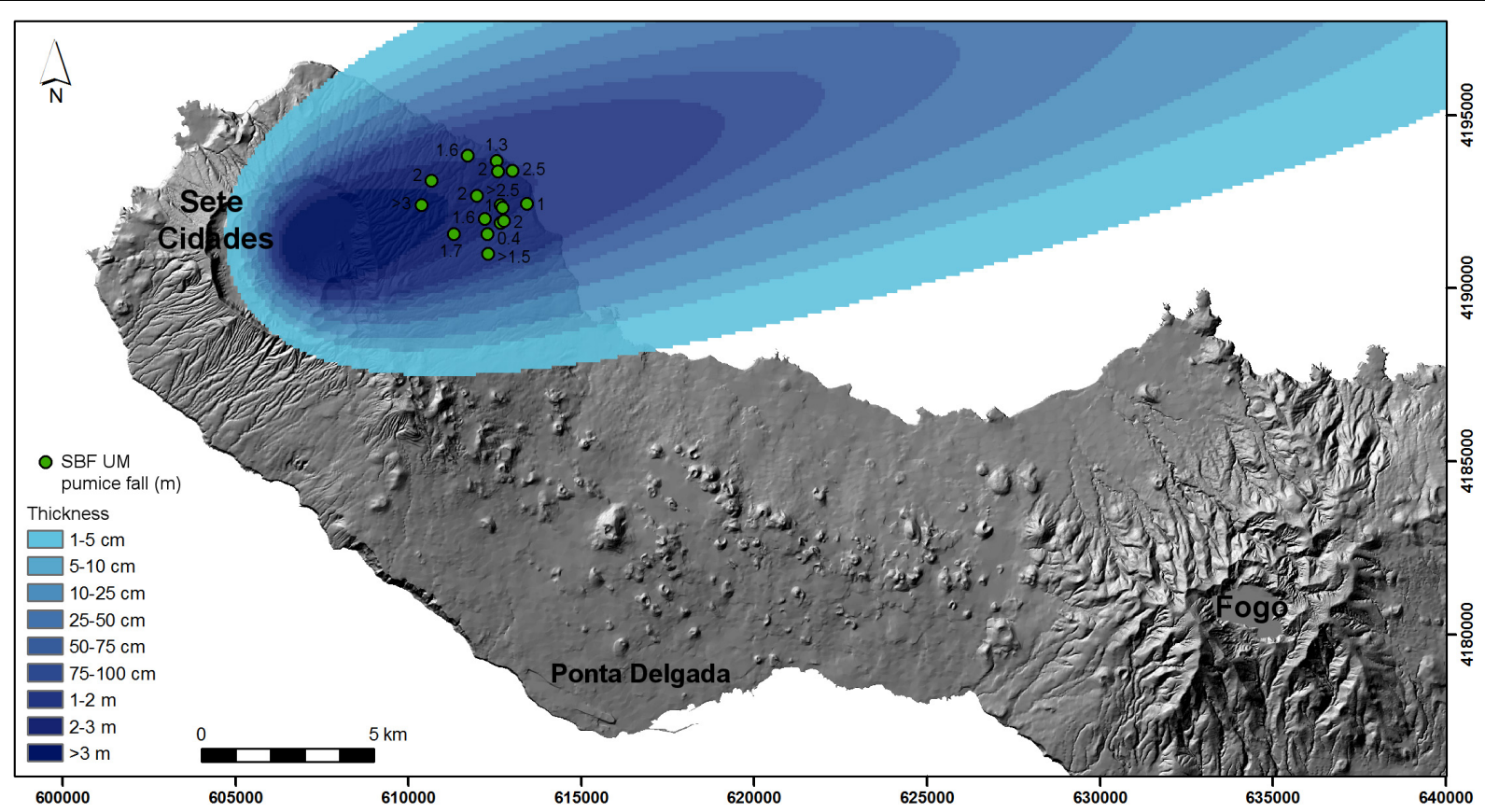

FIGURE 6 | Scenario 1 tephra fall map resulting from the simulations with VORIS 2.0.1, reconstructing the thickness of the proximal pumice fall deposit of the Upper Member of the SBF. Strong and unidirectional winds are interpreted to limit the dispersal and deposition to a narrow sector.

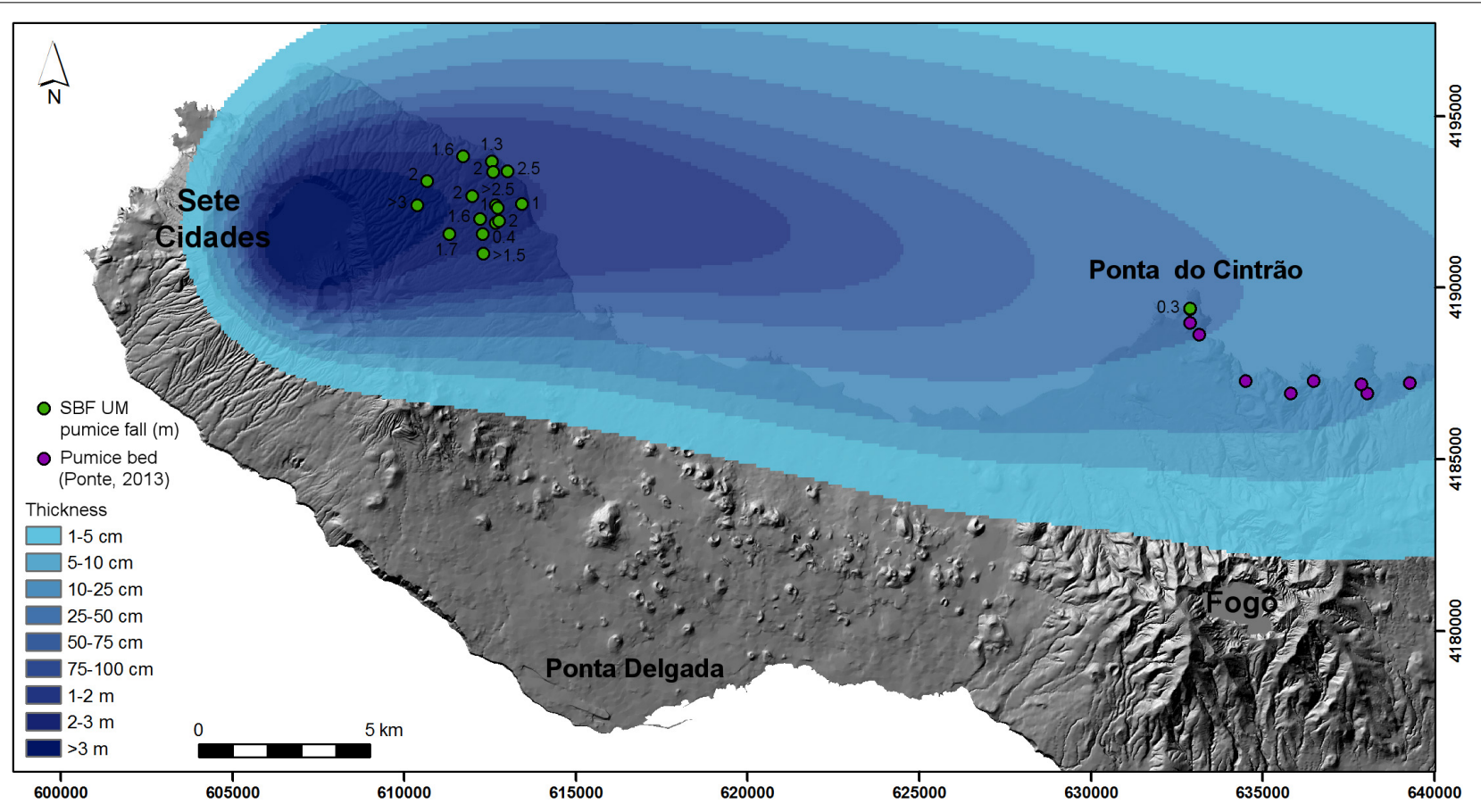

FIGURE 7 | Scenario 2 tephra fall map resulting from the simulations with VORIS 2.0.1, reconstructing the distribution of the proximal and mid-distal pumice fall deposit of the Upper Member of the SBF. Complex wind profile blowing from SW at lower altitude and from WNW at higher altitude are interpreted to be responsible for the deposition along the north coast of São Miguel.

The detailed analysis of $>150$ proximal outcrops on the flanks of $7 \mathrm{C}$ allowed for reconstructing the stratigraphy and related eruption history of the SBF (Kueppers et al., 2007, 2009;
Porreca et al., 2018). The extension of the study area further to the east revealed the existence of a mid-distal deposit on the north flank of Fogo volcano, on the Ponta do Cintrão 


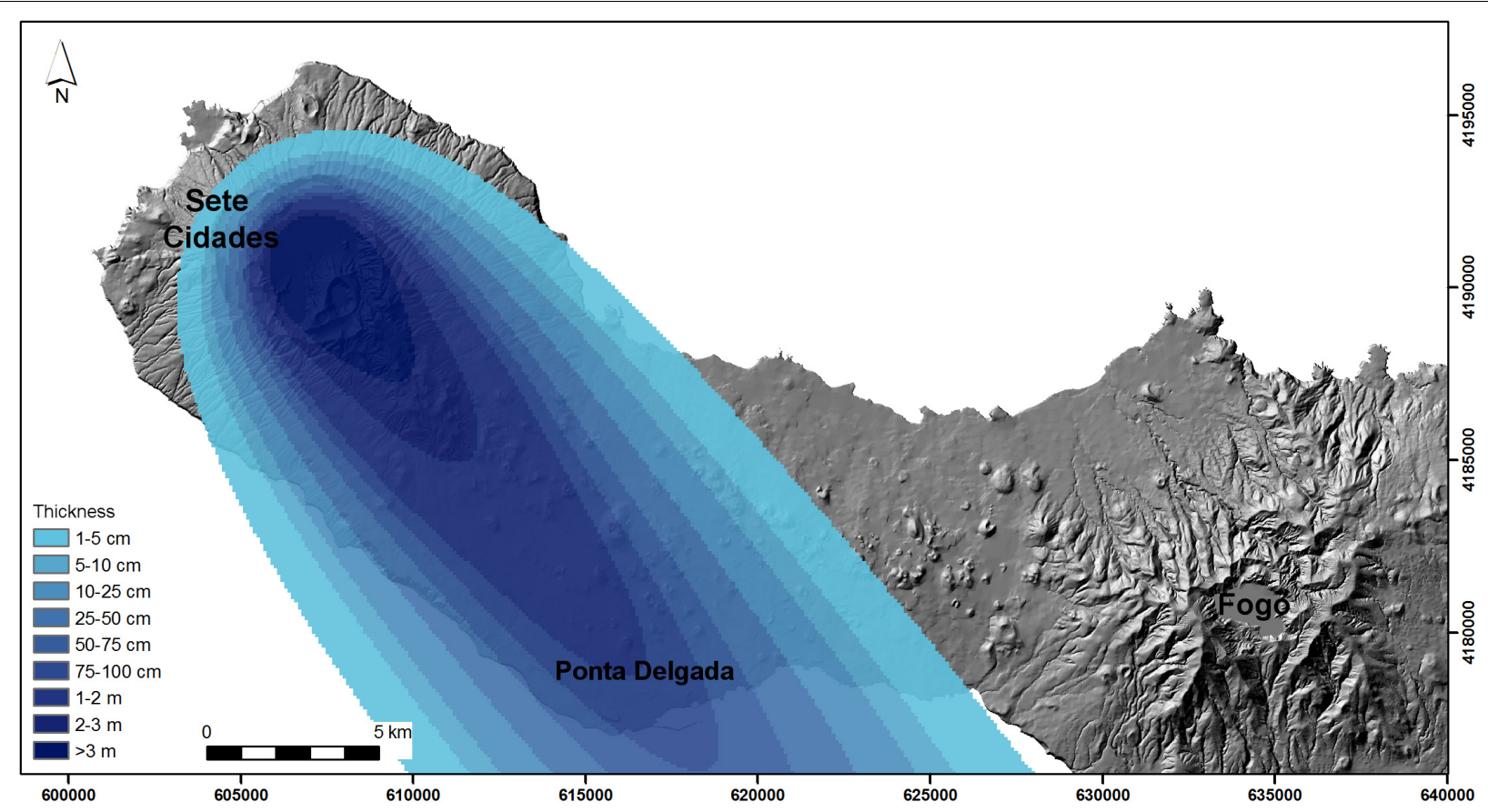

FIGURE 8 | Scenario 3 tephra fall map resulting from the simulations with VORIS 2.0.1, showing the potential impact of a future explosive eruption of Sete Cidades volcano, with the same eruptive source parameters obtained for scenario 2 and wind blowing from NW.

peninsula ( $\sim 100 \mathrm{~m}$ a.s.l.). Here, a $30 \mathrm{~cm}$-thick, well-sorted, clastsupported bed composed of pumice clasts (average maximum size of $4 \mathrm{~cm}$ ), dispersed lithic clasts (up to $2 \mathrm{~cm}$ across) and small obsidian fragments can be found. The pumice clasts are typically yellowish and contain abundant MME. The angular shape of the pumices and the clast-supported nature strongly suggest a primary fall deposit. This outcrop on the Ponta do Cintrão peninsula is the westernmost outcrop of pumice lapilli beds containing black inclusions described by Ponte (2013) on the north flank of Fogo volcano. Their textural similarity to the Ponta do Cintrão bed described here is striking and allows for extending its distribution to $>9 \mathrm{~km}$ east of Ponta do Cintrão (Supplementary Figure S1). The presence of MME in trachytic pumice clasts from Fogo and Furnas volcanoes has never been described (N. Wallenstein personal communication; cf. Guest et al., 1999, 2015; Wallenstein, 1999; Wallenstein et al., 2015), making it a unique characteristic of the SBF deposits of 7C volcano.

A combination of textural and geochemical analyses, together with field characteristics, has shown that this pumice bed corresponds to the mid-distal part of the pumice fall deposit of the Upper Member of the SBF. At Ponta do Cintrão peninsula $>25 \mathrm{~km}$ distance from $7 \mathrm{C}$ caldera, the proximally observed separation into two pumice lapilli beds by a thin ash-rich layer is absent. We hypothesize that the interpreted unsteadiness of the eruption column was not recorded in the distal portion of the deposit.

The restricted dispersal of the proximal SBF Upper Member pumice fall deposit to a very narrow sector of the NE flank of $7 \mathrm{C}$ has been interpreted as the effect of deposition from an eruption column strongly controlled by SW-blowing wind. This local geographic restriction and the fairly homogeneous thickness and grain size do not allow the construction of isopach and isopleth maps, thereby limiting our ability to precisely determine eruptive source parameters and wind conditions. However, the finding of mid-distal deposits to the east of 7C volcano provides information for a quantitative analysis of fall dispersal and wind field conditions. The simulations performed in this study show the influence of different wind conditions on tephra fallout in the three considered scenarios. The effect of wind on the deposition of tephra has long been appreciated, manifested in deposits with:

- radial symmetry due to no wind or low wind intensity [e.g., Pululahua, Ecuador (Papale and Rosi, 1993) and Fogo A, Azores (Figure 2 in Walker and Croasdale, 1970)];

- bilateral symmetry due to simple wind conditions for 1 day [e.g., Eyjafjallajökull, Iceland (Figure 3 of Gudmundsson et al., 2012) and Shinmoe-dake, Japan (Figure 8A of Nakada et al., 2013)] or entire eruption sequences [e.g., Montagne Pelée, Martinique (Figures 5, 6 of Carazzo et al., 2012) and Fogo 1563, Azores (Walker and Croasdale, 1970)];

- curved dispersal axes due to complex wind conditions [Shinmoe-dake, Japan (Figures 8B,C of Nakada et al., 2013)]; or

- complex tephra deposition due to strong variability in wind direction [e.g., Cordon Caulle, Chile (Figure 7 and Table 2 of Pistolesi et al., 2015) and Laacher See, Germany (Figure 1 of Van den Boogard and Schmincke, 1985)]. 
Leder et al. (2017) used published eruptive source parameters for the Laacher See eruption, Germany, to model the tephra loading assuming a simple wind field in order to assess the possible loss in infrastructure by roof collapse. In the present case, the observed distribution of the SBF pumice fall deposit from proximal to mid-distal areas on São Miguel Island is interpreted as the result of complex wind conditions (variable direction and intensity with increasing altitude).

Given the short distance between the assumed vent location and the coastline, Porreca et al. (2018) estimated that only a minor fraction $(<10 \%)$ of the total erupted volume of the SBF $\left(0.3 \mathrm{~km}^{3}\right)$ was deposited on land. Here, we constrained eruption column height, erupted volume and wind conditions of the final sub-Plinian phase of the eruption (recorded in the Upper Member) by best-fitting the observed thickness of the pumice fall deposit in proximal and distal areas. This pumice fall deposit can be taken as a proxy to estimate the overall size of the eruption. Accordingly, the estimated eruption column height is $17,000 \mathrm{~m}$, which should be considered as a lower estimate. Taking in account the observed field relations (Porreca et al., 2018), we conservatively estimate that the pumice fall deposit of the Upper Member $\left(0.27 \mathrm{~km}^{3}\right)$ corresponds to about $25 \%$ of the SBF volume. This yields a total erupted volume for the SBF of at least $1.08 \mathrm{~km}^{3}$, which is 3.6 times more than previously estimated by Porreca et al. (2018). In terms of DRE volume, this corresponds to about $0.25-0.54 \mathrm{~km}^{3}$ of magma, assuming a deposit density between 550 and $1200 \mathrm{~kg} / \mathrm{m}^{3}$ and a trachytic magma density of $2400 \mathrm{~kg} / \mathrm{m}^{3}$ (Pimentel et al., 2015). This is in agreement with the general idea that single paroxysmal events in the Azores probably do not exceed $1 \mathrm{~km}^{3}$ DRE (Gertisser et al., 2010; Pimentel et al., 2015), as consistent with the small size of the Azorean calderas $\left(<6 \mathrm{~km}^{3}\right)$ and the evidence that they are enlarged incrementally through a series of major explosive eruptions (Walker, 1984; Pimentel et al., 2015).

\section{Insights Into Hazard Assessment}

There is no doubt that a future explosive eruption of 7C would severely impact the village of Sete Cidades located inside caldera, but also all villages along the volcano's flanks. However, the finding of a mid-distal portion of the Upper Member of the SBF deposits provides evidence that a future explosive eruption with similar characteristics has the potential to strongly impact most of the island. Importantly, all major infrastructure (main harbor, airport and hospital) are concentrated in the island's capital, the city of Ponta Delgada, only $\sim 12 \mathrm{~km}$ downwind from $7 \mathrm{C}$ caldera. The recent ( $<5 \mathrm{ky}$ ) eruptive history of $7 \mathrm{C}$ was marked by at least 17 trachytic intra-caldera explosive eruptions, some of which of sub-Plinian dimensions, and 12 basaltic flank eruptions (Booth et al., 1978; Queiroz, 1997; Cole et al., 2008; Queiroz et al., 2008, 2015). This high eruptive frequency makes 7C the most active volcano in the Azores in the recent geological past. The last intra-caldera explosive eruption (P17) occurred $\sim 700$ years ago (Queiroz et al., 2008) and took place prior to the settlement of the Azores in the first half of the 15th century (Beier and Kramer, 2018). Based on available age constraints, the average eruption recurrence time of around 300 years has already been exceeded (Gaspar et al., 2015). Although 7C is closely monitored since
1998 by a network of seismic stations and episodic GPS/GNSS campaigns, seismic activity is low when compared with Fogo and Furnas volcanoes. The last seismic unrest occurred in 1998 inside the caldera and to the NW (Queiroz et al., 2015). Since then, 7C volcano has been relatively quiet.

Next, we discuss the impact of tephra fallout in proximal and mid-distal areas according to the three scenarios considered in the present work. All of them have a severe impact on São Miguel Island. In proximal areas (i.e., on the flanks of 7C), thick tephra fallout (but also PDCs, not simulated in this study) can have devastating consequences with similar impact assumed for the three scenarios. Buildings and infrastructure (roads, power lines, etc.) are expected to become damaged/destroyed by dynamic pressures (PDC) or load (tephra fall). Ground transportation and radio communication can be disrupted. Severe damage to vegetation, agricultural areas and water sources is also expected. Health hazards including respiratory problems due to ash and volcanic gasses can affect the local population (for a detailed review of the impacts of volcanic ash see Wilson et al., 2012, 2014). The different impacts on medial and distal areas, based on simulation results, are presented next.

Scenario 1 assumes a small sub-Plinian eruption with winds blowing from WSW (Figure 6) as reconstructed only from the distribution of the proximal pumice fall deposit of the Upper Member of the SBF. In this case, $0.19 \mathrm{~km}^{3}$ of tephra are raining out from a 12,000 $\mathrm{m}$ high eruption column (Table 2) and cover the NE flank of 7C (between João Bom and Capelas villages) with up to $3 \mathrm{~m}$ thick deposits. Most of the material is going to be deposited into the ocean and form potentially thick and coherent pumice rafts. Depending on wind, wave and currents, pumice rafts may remain afloat for weeks to months (cf. Jutzeler et al., 2014) and will severely affect - if not halt marine operations along the north coast of São Miguel and make important fishery ports (such as Rabo de Peixe) nonoperational. Volcanic ash would shut down the international airport at Ponta Delgada as well as cause the partial closing of the airspace over the Azores, affecting inter-island traffic. At constant wind direction and intensity, the ash plume can reach Europe around NW Spain ( $\sim 1500 \mathrm{~km}$ distance) and affect flights between Central/SW Europe and Central/South America. As seen in the case of the 2010 Eyjafjallajökull eruption (Iceland) volcanic ash reached central Europe in less than 2 days (Gasteiger et al., 2011) and caused several days of airspace closure. In this scenario, the central and eastern part of São Miguel is not affected by tephra fallout and can likely serve as a retreat area in case of evacuation, similar to the case of Montserrat (West Indies) in 1995 when the population was evacuated to the northern part of the island (Kokelaar, 2002). Of the three considered scenarios, this is the one with the smallest impact on São Miguel and major infrastructure (hospital, port) are likely not affected.

Scenario 2 accounts for a larger sub-Plinian eruption with winds blowing from SW at lower altitude and from WNW at higher altitude (Figure 7) as reconstructed based on the proximal and mid-distal pumice fall deposit of the Upper Member of the SBF. Approximately $42 \%$ more tephra $\left(0.27 \mathrm{~km}^{3}\right)$ is being erupted compared to scenario 1 from an eruption column up to $17,000 \mathrm{~m}$ high. The proximal deposits are expected to extend 
further westwards to Mosteiros and cover most of the inhabited areas along the north coast of São Miguel (affecting $>50,000$ persons in the villages of Capelas, Rabo de Peixe, Ribeira Grande, Porto Formoso, and Maia). These villages can be affected by $10-25 \mathrm{~cm}$ of tephra fall, which is enough to collapse $\sim 50 \%$ of the weakest types of roofs in São Miguel (Booth et al., 1983; Pomonis et al., 1999; Cole et al., 2008). As the area directly affected by tephra fall is substantially larger and comprises approximately half of São Miguel Island, human movement will be impaired by cutting off the main road along the north coast. The pumice deposit can likely have a severe impact on the two geothermal power plants located in the north slope of Fogo volcano. Marine operations would be affected to a comparable degree as in scenario 1 . Volcanic ash would shut down the international airport at Ponta Delgada as well as cause the partial closing of the airspace over the Azores, affecting inter-island traffic. At constant wind direction and intensity, the ash plume can reach Europe near Portugal $(\sim 1500 \mathrm{~km}$ distance $)$ within 2 days and shut down flights between Europe and Central/South America as well as flights to the Canary Islands. In this scenario, the south part of São Miguel is not affected by tephra fallout and can serve as a retreat area in case of evacuation of the villages located on the north coast. The area of land that can still be used for human activities is significantly reduced, yet, the hospital and main harbor may continue to operate under emergency conditions.

Scenario 3 is based on a hypothetical future eruption with the same eruptive source parameters of scenario 2, under wind conditions blowing toward Ponta Delgada (Figure 8) The eruptive source parameters (erupted volume $0.27 \mathrm{~km}^{3}$; column height $17,000 \mathrm{~m}$ ) obtained from the reconstruction of the pumice fall deposit of the Upper Member of the SBF, through the solution of the inverse problem, are within the same range of values of the parameters of recent $(<5 \mathrm{ky})$ intra-caldera eruptions of 7C (see Cole et al., 2008; Queiroz et al., 2008). This suggests that this pumice fall deposit can be used as a proxy for a future sub-Plinian eruption of 7C. Furthermore, in this case, more than 100,000 persons live in areas that can be affected by up to $1 \mathrm{~m}$ of tephra fall, including the capital Ponta Delgada (with Fajã de Cima, Fajã de Baixo, and São Roque in the direct periphery) and Lagoa, the third-largest city $(15,000$ inhabitants). This thickness of tephra is enough to cause the collapse of almost all buildings, including modern constructions reinforced with concrete (Spence et al., 2005; Cole et al., 2008). In this scenario the airport, the main harbor and critical infrastructure, such as the hospital are not operational, preventing immediate evacuation measures or arrival of first aid goods. At constant wind direction and intensity, the ash plume would reach the Madeira archipelago $(\sim 1000 \mathrm{~km}$ distance $)$ and the Canary Islands $(\sim 1300 \mathrm{~km})$ within 1 or 2 days and affect air traffic to these islands, in Northern Africa and between Europe and South America.

Although 7C volcano did not erupt in historic times, the 1563 eruption of Fogo volcano (Walker and Croasdale, 1970; Aguiar et al., 2018) and the 1630 eruption of Furnas volcano (Cole et al., 1995) provide evidence of the severe impact that
sub-Plinian eruptions had on São Miguel in the past when the population density was much smaller. In the case of a future subPlinian eruption of 7C under the predominant westerly blowing winds, the local impact on the island itself will be catastrophic, likely leaving a long-term effect, with economic consequences for the entire Azores archipelago. As illustrated by scenario 3, the island of São Miguel with an estimated population of $>137,000$ inhabitants, cannot be reached by major transportation devices, making evacuation or delivery of supplies very difficult. In the light of this and nonetheless the relatively low probability of such an event, this worst-case scenario should be part of hazard assessment strategies.

The volcanic hazard potential of 7C therefore should not be underestimated and the probability for future explosive eruptions should not be ignored. This work represents a first attempt to perform a realistic assessment of the impact of a major future explosive eruption of $7 \mathrm{C}$ on the island of São Miguel. The insights obtained here may be adopted as features of hazard assessment for other volcanic ocean islands prone to explosive eruptions. In general, this study has evidenced the importance of investigative prowess through synergetic studies of field work, textural/geochemical analyses and numerical simulations. A small number of additional, middistal to distal outcrops has proven to boost the precision of efforts to precisely constrain source parameters of past eruptions. In future, a supra-disciplinary approach involving scientists working on subaerial deposits, coring seafloor sediments and investigating ice cores should push our current limits of understanding of past eruptions on volcanic ocean islands or in remote positions.

\section{CONCLUSION}

Sete Cidades (7C) is the volcano with the highest eruptive frequency in the Azores archipelago in the past $5 \mathrm{ky}$. The last major explosive eruption $(\sim 16 \mathrm{ka})$ enlarged the summit caldera to its present-day dimensions and produced a complex pyroclastic sequence known as the Santa Bárbara Formation (SBF). As on many other ocean island volcanoes, the eruption record is incomplete because of primary (large volume of tephra deposited on the ocean and widespread cover of younger deposits) and secondary (significant erosion) reasons that hinder the determination of eruptive source parameters.

New fieldwork, textural and geochemical data of a formerly uncorrelated pumice bed on the north flank of Fogo volcano allowed for its unequivocal correlation with the proximal pumice fall deposit of the Upper Member of the SBF. Numerical simulations reconstructed the proximal and distal dispersal of the pumice fall deposit and quantitatively constrained eruptive source parameters and wind conditions. Three different scenarios were considered to assess the impact of tephra fallout on São Miguel Island. Two scenarios (with and without accounting for the mid-distal part of the pumice fall deposit) have shown the strong influence of wind on tephra dispersal. The constrained eruptive source parameters were used to envisage a third scenario assuming wind blowing toward the island's capital. In this worst, 
but plausible, scenario the city of Ponta Delgada (including main harbor, hospital and airport) and surrounding communities would be affected by up to $1 \mathrm{~m}$ of tephra.

Although 7C volcano has not erupted in historical times and is currently considered dormant, its potential to generated hazardous explosive eruptions should not be overlooked. Worstcase scenarios, such as the one considered in scenario 3 , need to be included in holistic approaches of volcanic hazard assessment on active volcanic islands.

\section{AUTHOR CONTRIBUTIONS}

UK and AP carried out the fieldwork. UK found the distal outcrop at Ponta do Cintrão during the course of Project M1.1.2/I/009/2005/A, guided and designed by JP and GQ. AP preformed the numerical simulations. BE, FF, and JN performed the geochemical analyses. DP co-supervised two undergraduate thesis at LMU. UK, AP, and BE drafted the manuscript. All authors have read and commented on the manuscript.

\section{FUNDING}

UK acknowledges Project M1.1.2/I/009/2005/A (Fundação Gaspar Frutuoso). BE acknowledges funding from the Swiss National Science Foundation (200021_166281). This study was additionally supported by the European

\section{REFERENCES}

Aguiar, S., Pacheco, J., and Pimentel, A. (2018). Eruptive history of the 1563 eruption of fogo volcano (S. Miguel, Azores). Geophys. Res. Abstr. 20, EGU2018EGU2776.

Armienti, P., Macedonio, G., and Pareschi, M. T. (1988). A numerical-model for simulation of tephra transport and deposition: applications to May 18, 1980, Mount St Helens eruption. J. Geophys. Res. 93, 6463-6476. doi: 10.1029/ JB093iB06p06463

Beier, C., Haase, K. M., and Hansteen, T. H. (2006). magma evolution of the sete cidades volcano. são miguel, azores. J. Petrol. 47, 1375-1411. doi: 10.1093/ petrology/egl014

Beier, R., and Kramer, J. (2018). "A portrait of the Azores: From natural forces to cultural identity," in Volcanoes of the Azores, Active Volcanoes of the World, eds U., Kueppers and C., Beier (Berlin: Springer), 3-26. doi: 10.1007/978-3-64232226-6_2

Biass, S., Scaini, C., Bonadonna, C., Folch, A., Smith, K., and Höskuldsson, A. (2014). A multi-scale risk assessment for tephra fallout and airborne concentration from multiple Icelandic volcanoes - part 1: hazard assessment. Nat. Hazards Earth Syst. Sci. 14, 2265-2287. doi: 10.5194/nhess-14-2265-2014

Bonasia, R., Capra, L., Costa, A., Macedonio, G., and Saucedo, R. (2011). Tephra fallout hazard assessment for a Plinian eruption scenario at volcán de colima (Mexico). J. Volcanol. Geotherm. Res. 203, 12-22. doi: 10.1016/j.jvolgeores.2011. 03.006

Bonasia, R., Macedonio, G., Costa, A., Mele, D., and Sulpizio, R. (2010). Numerical inversion and analysis of tephra fallout deposits from the $472 \mathrm{AD}$ sub-plinian eruption at vesuvius (Italy) through a new best-fit procedure. J. Volcanol. Geotherm. Res. 189, 238-246. doi: 10.1016/j.jvolgeores.2009.11.009

Booth, B., Croasdale, R., and Walker, G. P. L. (1978). "A quantitative study of five thousand years of volcanism on São Miguel, Azores," in Philosophical. Transactions of the Royal Society A, eds H. Tazieff and J. C. Sabroux (Amsterdam: Elsevier), 99-109.
Union's Seventh Framework Program FP7 "FP7PEOPLE-2013-ITN," under grant agreement number is 607905 - VERTIGO.

\section{ACKNOWLEDGMENTS}

UK thanks Catarina Goulart for her invaluable support with ArcGIS and Pedro Cerqueira, Roberto Hoge, and João Fontiela for logistical support during field work, Hilger Lohringer (LMU) for sample preparation for the theses of Dominik Fahrner and Gianluigi Ortenzi theses as well as Dirk Müller (LMU) for assistance with the microprobe. The authors thank the reviewers DP and FL as well as the editor RS and Valerio Acocella for their constructive comments.

\section{SUPPLEMENTARY MATERIAL}

The Supplementary Material for this article can be found online at: https://www.frontiersin.org/articles/10.3389/feart. 2019.00122/full\#supplementary-material

FIGURE S1 | Stratigraphic sections of nine outcrops along the north coast of São Miguel Island containing a pumice lapilli bed with black inclusions, highlighted in yellow (Ponte, 2013). In this study, this pumice fall bed is correlated to the Upper Member of the SBF.

TABLE S1 | Overview of values of trace elements for the 7 different sample sets.

Booth, B., Croasdale, R., and Walker, G. P. L. (1983). "Volcanic hazard on São Miguel, Azores," in Forecasting Volcanic Events. Developments in Volcanology, 1, eds H. Tazieff and J. C. Sabroux (Amsterdam: Elsevier), 99-109.

Carazzo, G., Tait, S., Kaminski, E., and Gardner, J. E. (2012). The recent Plinian explosive activity of Mt. Pelée volcano (Lesser Antilles): the P1 AD 1300 eruption. Bull. Volcanol. 74, 2187-2203. doi: 10.1007/s00445-012-0655-4

Carmo, R., Madeira, J., Ferreira, T., Queiroz, G., and Hipólito, A. (2015). "Volcanotectonic structures of São Miguel Island, Azores," in Volcanic Geology of São Miguel Island (Azores Archipelago), eds J. L., Gaspar, J. E., Guest, A. M., Duncan, F. J. A. S., Barriga, and D. K., Chester (London: Geological Society London), 65-86. doi: 10.1144/M44.6

Cole, P. D., Pacheco, J. M., Gunasekera, R., Queiroz, G., Gonçalves, P., and Gaspar, J. L. (2008). Contrasting styles of explosive eruption at sete cidades, são miguel, azores, in the last 5000 years: hazard implications from modeling. J. Volcanol. Geotherm. Res. 178, 574-591. doi: 10.1016/j.volgeores.2008.01.008

Cole, P. D., Queiroz, G., Wallenstein, N., Gaspar, J. L., Duncan, A. M., and Guest, J. E. (1995). An historic subplinian to phreatomagmatic eruption: the 1630 eruption of furnas volcano, sao miguel, azores. J. Volcanol. Geotherm. Res. 69, 117-135. doi: 10.1016/0377-0273(95)00033-X

Costantini, L., Bonadonna, C., Houghton, B. F., and Wehrmann, H. (2009). new physical characterization of the fontana lapilli basaltic plinian eruption, nicaragua. Bull. Volcanol. 71, 337-355. doi: 10.1007/s00445-0080227-9

Dinis, L. M. (2006). Contribuição Para A Definição Da Escala Vulcanoestratigrafica Da Ilha De São Miguel (Açores). M.Sc. Thesis, Azores University, Portugal.

Fahrner, D. (2012). Comparison Of Pumice Clasts From Proximal And Distal Fall Deposits Of Sete Cidades Volcano (São Miguel, Azores): Do They Belong To The Same Eruption?. M.Sc. thesis, Ludwig-Maximilians-Universität Munich, Germany.

Felpeto, A., Martí, J., and Ortiz, R. (2007). Automatic GIS-based system for volcanic hazard assessment. J. Volcanol. Geotherm. Res. 166, 106-116. doi: 10.1016/j. jvolgeores.2007.07.008 
Folch, A., and Felpeto, A. (2005). A coupled model for dispersal of tephra during sustained explosive eruptions. J. Volcanol. Geotherm. Res. 145, 337-349. doi: 10.1016/j.jvolgeores.2005.01.010

Gaspar, J. L., Guest, J. E., Queiroz, G., Pacheco, J., Pimentel, A., Gomes, A., et al. (2015). "Eruptive frequency and volcanic hazards zonation in São Miguel Island, Azores," in Volcanic Geology of São Miguel Island (Azores Archipelago), eds J. L. Gaspar, J. E. Guest, A. M. Duncan, F. J. A. S. Barriga, and D. K. Chester (London: Geological Society London), 155-166. doi: 10.1144/M44.12

Gasteiger, J., Groß, S., Freudenthaler, V., and Wiegner, M. (2011). Volcanic ash from Iceland over Munich: mass concentration retrieved from ground-based remote sensing measurements. Atmos. Chem. Phys. 11, 2209-2223. doi: 10. 5194/acp-11-2209-2011

Gertisser, R., Self, S., Gaspar, J. L., Kelley, S. P., Pimentel, A., Eikenberg, J., et al. (2010). "Ignimbrite stratigraphy and chronology on Terceira Island, Azores," in Stratigraphy and geology of volcanic areas, eds G. Groppelli and L. ViereckGoette (London: Geological Society London), 133-154.

Gonçalves, P. (2006). Caracterização do depósito sete-p11 (sete cidades, s. Miguel, açores): Implicações Para a História Eruptiva. M.Sc. Thesis, Azores University, Portugal.

Gudmundsson, M. T., Thordarson, T., Höskuldsson, A., Larsen, G., Björnsson, H., Prata, F. J., et al. (2012). Ash generation and distribution from the AprilMay 2010 eruption of Eyjafjallajökull, Iceland. Sci. Rep. 2:572. doi: 10.1038/ srep00572

Guest, J. E., Gaspar, J. L., Cole, P. D., Queiroz, G., Duncan, A. M., Wallenstein, N., et al. (1999). Volcanic geology of Furnas volcano. São Miguel, Azores. J. Volcanol. Geotherm. Res. 92, 1-29. doi: 10.1016/S0377-0273(99)00064-5

Guest, J. E., Pacheco, J. M., Cole, P. D., Duncan, A. M., Wallenstein, N., Queiroz, G., et al. (2015). "The volcanic history of Furnas Volcano, São Miguel, Azores," in Volcanic Geology of São Miguel Island (Azores Archipelago), eds J. L. Gaspar, J. E. Guest, A. M. Duncan, F. J. A. S. Barriga, and D. K. Chester (London: Geological Society London), 125-134. doi: 10.1144/M44.9

Guillong, M., Meier, D., Allan, M., Heinrich, C., and Yardley, B. (2008). Laser Ablation ICP-MS in the Earth Sciences: Current Practices and Outstanding Issues. Canada: Mineralogical Association of Canada, 328-333.

Heiken, G., and McCoy, F. Jr. (1984). Caldera development during the minoan eruption, thira, cyclades, greece. J. Geophys. Res. 89, 8441-8462. doi: 10.1029/ JB089iB10p08441

Johansson, H., Lind, E. M., and Wastegard, S. (2017). Compositions of glass in proximal tephras from eruptions in the azores archipelago and their links with distal sites in Ireland. Quat. Geochronol. 40, 120-128. doi: 10.1016/j.quageo. 2016.07.006

Jutzeler, M., Marsh, R., Carey, R. J., White, J. D. L., Talling, P. J., and Karlstrom, L. (2014). On the fate of pumice rafts formed during the 2012 havre submarine eruption. Nat. Commun 5:3660. doi: 10.1038/ncomms4660

Kokelaar, B. P. (2002). "Setting, chronology and consequences of the eruption of Soufriere Hills Volcano, Montserrat (1995-1999)," in The Eruption of Soufriere Hills Volcano, Montserrat, from 1995 to 1999, eds T. H. Druitt and B. P. Kokelaar (London: Geological Society, London), 1-44. doi: 10.1144/GSL.MEM.2002. 021.01 .02

Kueppers, U., Beier, C., Genske, F. S., and Caetano, D. (2018). "Where to Go? A Selection and Short Description of Geological Highlights in the Azores," in Volcanoes of the Azores, Active Volcanoes of the World, eds U. Kueppers and C. Beier (Berlin: Springer), 331-355. doi: 10.1007/978-3-642-32226-6_14

Kueppers, U., Pimentel, A., and Pacheco, J. (2009). The 16 ka eruption of sete cidades volcano, são miguel island (Azores, Portugal): hazard assessment from mapping and simulation of tephra fall. Geophys. Res. Abstr. 11, EGU2009EGU10816.

Kueppers, U., Queiroz, G., and Pacheco, J. (2007). Eruptive and Transportation Processes During Caldera-Forming Eruptions of Sete Cidades Volcano, São Miguel, Azores. AGU Fall Meeting 2007. San Francisco, CA

Laeger, K., Petrelli, M., Morgavi, D., Lustrino, M., Pimentel, A., Paredes-Mariño, J., et al. (2019). Pre-eruptive conditions and triggering mechanism of the $\sim 16 \mathrm{ka}$ santa bárbara explosive eruption of sete cidades volcano (São Miguel. Azores). Contrib. Mineral. Petrol. 174:11. doi: 10.1007/s00410-019-1545-y

Leder, J., Wenzel, F., Daniell, J. E., and Gottschämmer, E. (2017). Loss of residential buildings in the event of a re-awakening of the laacher see volcano (Germany). J. Volcanol. Geotherm. Res. 337, 111-123. doi: 10.1016/j.jvolgeores.2017.02.019
Longchamp, C., Bonadonna, C., Bachmann, O., and Skopelitis, A. (2011). Characterization of tephra deposits with limited exposure: the example of the two largest explosive eruptions at Nisyros volcano (Greece). Bull. Volcanol. 73, 1337-1352. doi: 10.1007/s00445-011-0469-9

Macedonio, G., Costa, A., and Folch, A. (2008). Ash fallout scenarios at vesuvius: numerical simulations and implications for hazard assessment. J. Volcanol. Geotherm. Res. 178, 366-377. doi: 10.1016/j.jvolgeores.2008.08.014

Mazzocchi, M., Hansstein, F., and Ragona, M. (2010). The 2010 volcanic ash cloud and its financial impact on the European airline industry. CESifo Forum 11, 92-100.

Moiseenko, K., and Malik, N. (2019). Linear inverse problem for inferring eruption source parameters from sparse ash deposit data as viewed from an atmospheric dispersion modeling perspective. Bull. Volcanol. 81:19. doi: 10.1007/s00445019-1281-1

Moore, R. (1990). Volcanic geology and eruption frequency. São Miguel, Azores. Bull. Volcanol. 52, 602-614. doi: 10.1007/BF00301211

Nakada, S., Nagai, M., Kaneko, T., Suzuki, Y., and Maeno, F. (2013). The outline of the 2011 eruption at Shinmoe-dake (Kirishima). Japan. Earth Planets Space 65:1. doi: 10.5047/eps.2013.03.016

Ortenzi, G. (2014). Sete Cidades volcano (são miguel, azores) 16 kyr b.p. Explosive Eruption: $2 d$ and $3 d$ Analyses of Pumice Samples. M.Sc. Thesis (Tesi di Laurea), Università di Perugia, Italy.

Papale, P., and Rosi, M. (1993). A case of no-wind plinian fallout at Pululagua caldera (Ecuador): implications for models of clast dispersal. Bull. Volcanol. 55:523. doi: 10.1007/BF00304594

Paredes-Mariño, J., Dobson, K. J., Ortenzi, G., Kueppers, U., Morgavi, D., Petrelli, M., et al. (2017). Enhancement of eruption explosivity by heterogeneous bubble nucleation triggered by magma mingling. Sci. Rep. 7, 1-10. doi: 10.1038/s41598017-17098-3

Pedrazzi, D., Cappello, A., Zanon, V., and Del Negro, C. (2015). Impact of effusive eruptions from the eguas-carvão fissure system. são miguel island, azores archipelago (Portugal). J. Volcanol. Geotherm. Res. 291, 1-13. doi: 10.1016/j. jvolgeores.2014.12.012

Pimentel, A., Pacheco, J., and Self, S. (2015). The 1000-years BP explosive eruption of caldeira volcano (Faial. Azores): the first stage of incremental caldera formation. Bull. Volcanol. 77:42. doi: 10.1007/s00445-015-0930-2

Pimentel, A., Pacheco, J. M., and Felpeto, A. (2006). Influence of wind patterns on the dispersal of volcanic plumes in the Azores region: test study of the 1630 eruption of furnas volcano (S. Miguel, Azores). Geophys. Res. Abstr. 8, EGU06-A-04983.

Pistolesi, M., Cioni, R., Bonadonna, C., Elissondo, M., Baumann, V., Bertagnini, A., et al. (2015). Complex dynamics of small-moderate volcanic events: the example of the 2011 rhyolitic cordon caulle eruption. Chile. Bull. Volcanol. 77:1. doi: 10.1007/s00445-014-0898-3

Pomonis, A., Spence, R. J. S., and Baxter, P. J. (1999). Risk assessment of residential buildings for an eruption of furnas volcano. são miguel, the azores. J. Volcanol. Geotherm. Res. 92, 107-131. doi: 10.1016/S0377-0273(99)00071-2

Ponte, D. (2013). Contribuição para o Conhecimento das Sequências Eruptivas dos Vulcões do Fogo e das Furnas, Entre Ribeirinha e Lomba da Maia, São Miguel (Açores). M.Sc. Thesis, Azores University, Portugal.

Porreca, M., Pimentel, A., Kueppers, U., Izquierdo, T., Pacheco, J., and Queiroz, G. (2018). Event stratigraphy and emplacement mechanisms of the last major caldera eruption on sete cidades volcano (são miguel, azores): the 16 ka santa bárbara formation. Bull. Volcanol. 80:76. doi: 10.1007/s00445-018-1250-0

Queiroz, G. (1997). Vulcão das Sete Cidades (S. Miguel, Açores): História Eruptiva e Avaliação do Hazard. Ph.D. Thesis, Azores University, Portugal.

Queiroz, G., Gaspar, J. L., Guest, J. E., Gomes, A., and Almeida, M. H. (2015). "Eruptive history and evolution of Sete Cidades Volcano, São Miguel Island, Azores," in Volcanic Geology of São Miguel Island (Azores Archipelago), eds J. L. Gaspar, J. E. Guest, A. M. Duncan, F. J. A. S. Barriga, and D. K. Chester (London: Geological Society of London), 87-104. doi: 10.1144/M44.7

Queiroz, G., Pacheco, J. M., Gaspar, J. L., Aspinall, W. P., Guest, J. E., and Ferreira, T. (2008). The last 5000 years of activity at sete cidades volcano (são miguel island, azores): implications for hazard assessment. J. Volcanol. Geotherm. Res 178, 562-573. doi: 10.1016/j.jvolgeores.2008.03.001

Scaini, C., Biass, S., Galderisi, A., Bonadonna, C., Folch, A., Smith, K., et al. (2014). A multi-scale risk assessment for tephra fallout and airborne concentration 
from multiple Icelandic volcanoes - part 2: vulnerability and impact. Nat. Hazards Earth Syst. Sci. 14, 2289-2312. doi: 10.5194/nhess-14-2289-2014

Scollo, S., Folch, A., and Costa, A. (2008). A parametric and comparative study of different tephra fallout models. J. Volcanol. Geotherm. Res. 176, 199-211. doi: 10.1016/j.jvolgeores.2008.04.002

Spanu, A., de' Michieli Vitturi, M., and Barsotti, S. (2016). Reconstructing eruptive source parameters from tephra deposit: a numerical study of medium-sized explosive eruptions at Etna volcano. Bull. Volcanol. 78:59. doi: 10.1007/s00445016-1051-2

Spence, R. J. S., Kelman, I., Calogero, E., Toyos, G., Baxter, P. J., and Komorowski, J.-C. (2005). Modelling expected physical impacts and human casualties from explosive volcanic eruptions. Nat. Hazards Earth Syst. Sci. 5, 1003-1015. doi: 10.5194/nhess-5-1003-2005

Suzuki, T. (1983). "A theoretical model for dispersion of tephra," in Arc volcanism: physics and tectonics, eds D. Shimozuru and I. Yokoyama (Tokyo: Terra Scientific Publishing Company), 95-116.

Szymanowski, D., Ellis, B. S., Bachmann, O., Guillong, M., and Phillips, W. M. (2015). Bridging basalts and rhyolites in the yellowstone-snake river plain volcanic province: the elusive intermediate step. Earth Planet. Sci. Lett. 415, 80-89. doi: 10.1016/j.epsl.2015.01.041

Van den Boogard, P., and Schmincke, H. U. (1985). laacher see tephra: a widespread isochronous late quaternary tephra layer in central and northern Europe. Geol. Soc. Am. Bull. 96, 1554-1571.

Walker, G. P. L. (1984). Downsag calderas, ring faults, caldera sizes, and incremental caldera growth. J. Geophys. Res. 89, 8407-8416. doi: 10.1029/ JB089iB10p08407

Walker, G. P. L., and Croasdale, R. (1970). Two Plinian-type eruptions in the Azores. J. Geol. Soc. 27, 17-55. doi: 10.1144/gsjgs.127. 1.0017
Wallenstein, N. (1999). Estudo da História Recente e do Comportamento Eruptivo do Vulcão do fogo (s. Miguel, açores). Avaliação Preliminar do Hazard. Ph.D. thesis, Azores University, Portugal.

Wallenstein, N., Duncan, A., Guest, J. E., and Almeida, M. H. (2015). "Eruptive history of Fogo Volcano, São Miguel, Azores," in Volcanic Geology of São Miguel Island (Azores Archipelago), eds J. L. Gaspar, J. E. Guest, A. M. Duncan, F. J. A. S. Barriga, and D. K. Chester (London: Geological Society of London), 105-123. doi: $10.1144 / \mathrm{M} 44.8$

Wilson, G., Wilson, T. M., Deligne, N. I., and Cole, J. W. (2014). Volcanic hazard impacts to critical infrastructure: a review. J. Volcanol. Geotherm. Res. 286, 148-182. doi: 10.1016/j.jvolgeores.2014.08.030

Wilson, L., and Huang, T. C. (1979). The influence of shape on the atmospheric settling velocity of volcanic ash particles. Earth Planet. Sci. Lett. 44, 311-324. doi: 10.1016/0012-821X(79)90179- 1

Wilson, T. M., Stewart, C., Sword-Daniels, V., Leonhard, G. S., Johnston, D. M., Cole, J. W., et al. (2012). Volcanic ash impacts on critical infrastructure. Phys. Chem. Earth 4, 5-23. doi: 10.1016/j.pce.2011.06.006

Conflict of Interest Statement: The authors declare that the research was conducted in the absence of any commercial or financial relationships that could be construed as a potential conflict of interest.

Copyright $\odot 2019$ Kueppers, Pimentel, Ellis, Forni, Neukampf, Pacheco, Perugini and Queiroz. This is an open-access article distributed under the terms of the Creative Commons Attribution License (CC BY). The use, distribution or reproduction in other forums is permitted, provided the original author(s) and the copyright owner(s) are credited and that the original publication in this journal is cited, in accordance with accepted academic practice. No use, distribution or reproduction is permitted which does not comply with these terms. 